\title{
The Median Is the Message: A Good- Enough Measure of Material Well-Being and Shared Development Progress
}

\section{Nancy Birdsall and Christian J. Meyer}

\begin{abstract}
We argue that survey-based median household consumption expenditure (or income) per capita be incorporated into standard development indicators, as a simple, robust, and durable indicator of typical individual material well-being in a country. Using household survey data available for low- and middle-income countries from the World Bank's PovcalNet tool, we show that as a measure of income-related well-being, it is far superior to the commonly used GDP per capita as well as survey-based measures at the mean. We also argue that survey-based median measures are "distributionaware", i.e. when used as the denominator of various widely available indicators such as mean consumption expenditure per capita they provide a "good-enough" indicator of consumption (or income) inequality. Finally, as a post-2015 indicator of progress at the country-level in promoting shared development and reducing inequality, we propose that the rate of increase in median consumption per capita after taxes and transfers exceed the rate of increase in average consumption in the same period.
\end{abstract}

JEL Codes: D31, H22, I32, O15

Keywords: welfare measure, median, consumption, inequality, distribution.
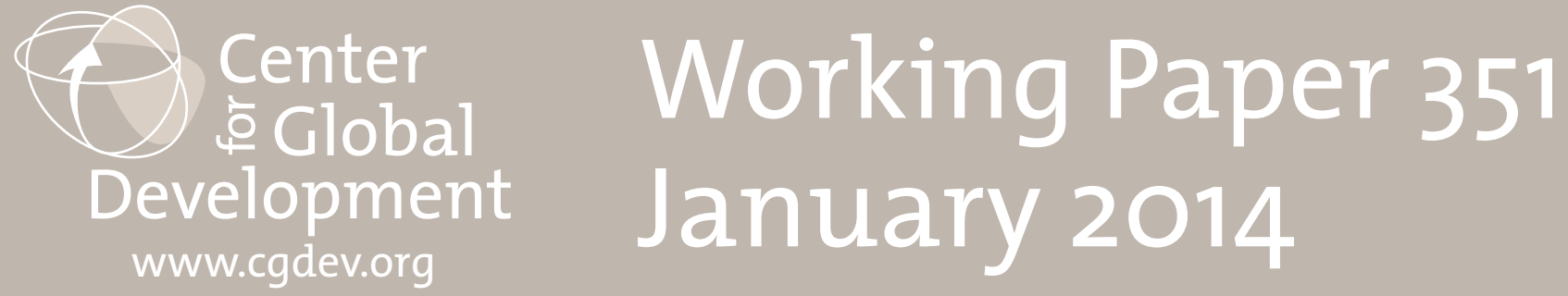


\title{
The Median Is the Message: A Good-Enough Measure of Material Well-Being and Shared Development Progress
}

\author{
Nancy Birdsall \\ Center for Global Development \\ Christian J. Meyer \\ Center for Global Development
}

nbirdsall@cgdev.org (corresponding author), cmeyer@cgdev.org. We thank Sarah Dykstra, Willa Friedman, Alan Gelb, Charles Kenny, Branko Milanovic, Mead Over, Lant Pritchett, Sneha Raghavan, Justin Sandefur and participants at the CGD conference on post-2015 inequality indicators for thoughtful comments. Dykstra and Sandefur generously shared data and code. The authors remain solely responsible for any errors..

CGD is grateful for contributions from the Swedish Ministry of Foreign Affairs, the Australian Agency for International Development, and the William and Flora Hewlett Foundation in support of this work.

Nancy Birdsall and Christian J. Meyer . 2014. "The Median Is the Message: A GoodEnough Measure of Material Well-Being and Shared Development Progress." CGD Working Paper 351. Washington, DC: Center for Global Development.

http:/ / www.cgdev.org/publication/median-message-good-enough-measure-material-wellbeing-and-shared-development-progress

Center for Global Development 2055 L Street., NW Washington, DC 20036

202.416.4000

(f) 202.416 .4050

www.cgdev.org
The Center for Global Development is an independent, nonprofit policy research organization dedicated to reducing global poverty and inequality and to making globalization work for the poor. Use and dissemination of this Working Paper is encouraged; however, reproduced copies may not be used for commercial purposes. Further usage is permitted under the terms of the Creative Commons License.

The views expressed in CGD Working Papers are those of the authors and should not be attributed to the board of directors or funders of the Center for Global Development. 


\section{Contents}

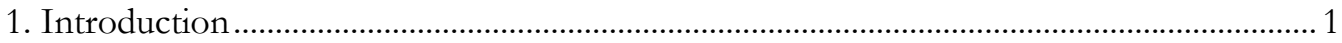

2. Why the median? Median household consumption expenditure as an indicator of

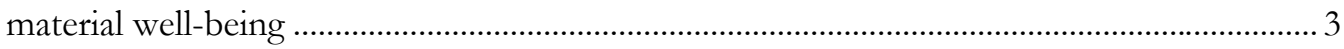

2.1 The median compared to the poverty rate................................................................ 3

2.2 The median compared to typical national accounts aggregates............................... 3

2.3 The international poverty lines are too low in two respects .................................. 7

2.4 Median consumption reflects well not only well-being of individuals but the state of development broadly defined ............................................................................... 9

3. The mean-to-median ratio as a simple measure of the distribution of material well-

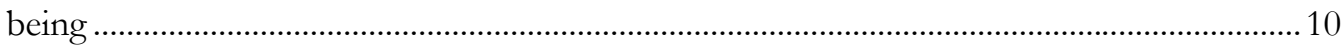

4. Measuring shared development progress …………........................................................ 12

5. Conclusion: Survey-based measures as development indicators for a new era.............15

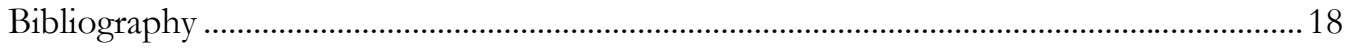

Appendix A: Comparing household survey-based income and consumption expenditure40 



\section{Introduction}

We argue that survey-based median household consumption expenditure (or income) per capita be incorporated into standard development indicators, as a simple, robust, and durable indicator of typical individual material well-being in a country (or in any geographical or other dimension such as gender, as well as over time in that dimension). As a measure of income-related well-being, we show that it is far superior to the commonly used gross domestic product (GDP) per capita as well as survey-based measures at the mean, as the mean measures exaggerate typical well-being due to the skewness in the consumption or income distributions of virtually all countries. We also argue that survey-based median measures are "distribution-aware", i.e. when used as the denominator of various widely available indicators such as mean consumption expenditure per capita they provide a "goodenough" indicator of consumption (or income) inequality; we show that the resulting ratios are closely associated with the Gini coefficient across countries. Finally, as an easily accessible post-2015 indicator of progress at the country-level in promoting shared development and reducing inequality, we propose that the rate of increase in median consumption per capita after taxes and transfers exceed the rate of increase in average consumption in the same period.

Median consumption expenditure per capita is not an alternative to the more conventional measures including those that measure the incidence and depth of poverty, nor the Gini coefficient, the Theil index and other measures of inequality. However it has the advantage of clarity and simplicity, and has not been used widely in the development literature only because the necessary data have not been available for widespread use.

However in the last decade the data situation has improved: (1) for most developing countries it is possible to measure income or consumption expenditure in purchasing power parity (PPP) terms, and with the publication of the most recent PPP data collected through the International Comparison Program (ICP), there is the promise that there will not be further major revisions in the methods; and (2) for most developing countries there are now high-quality household survey data on income or consumption which can be used to construct the entire distribution of income or consumption and thus the median. The World Bank has over the last two decades been investing in the public good of obtaining (funding directly in some cases), compiling, correcting, making consistent, and providing user-friendly access to information on the distributions of income or consumption based on household survey data. ${ }^{1}$

\footnotetext{
1 The World Bank is a founding member of three global work programs for statistical capacity building: The Partnership in Statistics for Development in the 21 ${ }^{\text {st }}$ Century (PARIS21), the Trust Fund for Statistical Capacity Building (TFSCB) and the Marrakech Action Plan for Statistics (MAPS). In the period from 2008 to 2010, commitments under PARIS21 amounted to roughly \$1.6 billion (Independent Evaluation Group, 2011, p. 30).
} 
Though public access to the underlying survey data is still highly restricted, in some cases by the countries that sponsor the surveys, the World Bank publishes basic summary statistics and Lorenz curve estimates for 923 household surveys through its PovcalNet online tool. ${ }^{2}$ Dykstra et al. (mimeo) describe a process of querying the tool to derive complete income and consumption distributions through the online interface. They provide a public dataset that replicates PovcalNet's estimates, which we are using in this paper.

With their early efforts to compile and harmonize income and consumption distributions based on household surveys, Ahluwalia et al. $(1979,1980)$ and others started the ball rolling for the World Bank to standardize and institutionalize the measurement of living standards through harmonized surveys. ${ }^{3}$

The original motivation for much of the World Bank's support for households surveys was better estimation of poverty rates and changes in poverty rates; possibly for that reason there has been no initiative to systematically estimate and publish medians (of income or consumption) comparable to the publication of poverty rates and poverty gaps. Meanwhile, beginning in the mid-1990s $\mathrm{s}^{4}$ the increasing availability of data on entire distributions, along with the growing interest in the broader development community about the relationships among poverty, inequality, growth and globalization has generated a large and growing body of analytic work on the measurement of income and consumption inequality and on its causes and consequences.

The rest of this paper is structured as follows. In the second section, we compare median household consumption expenditure (or income) per capita to other commonly used measures of material well-being at the country level, and argue for more attention to the median at the individual level in analyses of material welfare across countries and over time. In a third section, we demonstrate that the ratio of the mean to the median provides a reasonably good indicator of a country's income or consumption expenditure distribution, compared for example to the Gini coefficient. In a fourth section, we propose the change in median consumption expenditure or income compared to the change of average income as an easily calculated and accessible measure of shared prosperity as well as development progress broadly conceived. In a concluding section, we urge that standardized survey-based

\footnotetext{
2 The World Bank's PovcalNet is a product of the World Bank's research department and is available at http://iresearch.worldbank.org/PovcalNet/ (last accessed September 2013). Ravallion et al. (2009) and Chen and Ravallion (2010) provide further background on the methodology of the World Bank's poverty estimates.

${ }^{3}$ Deaton (2005) provides a good historical account of the debates on poverty and growth, including a history of survey-based poverty and inequality estimates. He argues that the comment by Ahluwalia et al. (1980) on Fields' (1977) study of the Brazilian economic miracle was an important impetus for the World Bank to establish the Living Standards Measurement Study (LSMS).

${ }^{4}$ Deininger and Squire helped pave the way with their inequality dataset (1996) and their subsequent study (1998). The research staff at the Inter-American Development Bank had by the mid-1990s developed consistent and comparable measures of household income across at least 18 of the 26 countries of the region (e.g. Londoño and Székely, 1997; Attanasio and Székely, 1999) which provided a basis for the major report, Facing Up to Inequality (Inter-American Development Bank, 1998).
} 
estimates of median consumption or income be added to the standard repertoire of development indicators compiled for example by the World Bank and the United Nations Development Program.

\section{Why the median? Median household consumption expenditure as an indicator of material well-being}

We begin with simple comparisons of median household consumption (or income) per capita with two types of more commonly used measures meant to reflect material well-being in developing countries: those based on household survey data (from the World Bank's PovcalNet online tool) using the poverty line of $\$ 2$ per capita per day at $2005 \mathrm{PPP} ; 5$ and those based on various national accounts aggregates.

\subsection{The median compared to the poverty rate}

Figure 1 shows survey-based median household consumption expenditure per capita per day on the vertical axis and national accounts-based gross national income (GNI) per capita on the horizontal axis; it also indicates the relationship of the former at the country level to the $\$ 2$ a day poverty line. The figure illustrates that for low-income countries, median consumption as a measure of typical material well-being provides information combining that in a country's poverty rate and poverty gap, and in a form that is more accessible than the poverty measures. In Ghana, Haiti, India, Kenya, for example, median income is below the $\$ 2$ a day line. For those countries the median makes clear that the poverty rate is 50 percent or greater; the absolute amount of the median captures information comparable to the poverty gap (Table 1).

\subsection{The median compared to typical national accounts aggregates}

The most commonly used measures of living standards of a population or economic development of a country more generally are based on national accounts aggregates, divided by the overall population, and sometimes adjusted for purchasing power parity. Indicators derived from national accounts have the advantage of being widely and frequently available in a standardized form - and the obvious disadvantage of being agnostic about the distribution of consumption, income, and wealth.

\footnotetext{
5 The World Bank's “main” poverty line is set at $\$ 1.25$, which is the average of the national poverty lines in the poorest 15 countries in the period from 1990 to 2005. The Bank also frequently reports poverty rates using a higher $\$ 2$ line, which is the median poverty line for all developing countries based on the compilation of Ravallion et al. (2009). Ravallion (2012) notes that $\$ 2$ is also very close to the median consumption per person in the developing world in 2005. Unless otherwise noted, dollar amounts in the remainder of the text refer to constant 2005 PPP dollars, based on the individual consumption rate from the 2005 International Comparisons Program.
} 
GDP per capita and GNI ${ }^{6}$ per capita are commonly used in the academic literature and by development practitioners. Since the first World Development Report was released by the World Bank in 1978, the Bank has used GNI per capita as the basis for classifying economies. Similarly, the United Nations Development Program's annual Human Development Report calculates the Human Development Index (HDI) based on GDP per capita (until 2009) and GNI per capita (2010 until today). ${ }^{7}$ Sub-components of GDP, most importantly the mean of household final consumption expenditure (HFCE), are also sometimes used for cross-country welfare or inequality analysis. ${ }^{8}$

Figure 1 indicates that compared to the median, national accounts estimates at the mean are often misleading in assessing the well-being of the poorer half of any population, if only because of the obvious advantage of the median over commonly used aggregate measures of average or mean GDP per capita and mean GNI per capita (for which there is no median to report in the first place). The figure shows Angola to be almost an upper-middle-income country according to the World Bank's classification, yet with median consumption expenditure of just $\$ 1.40$ per capita per day (and with more than two-thirds of the population living below the poverty line in 2009). The Philippines, a "typical" lower-middleincome country, though only about half as rich in terms of GNI per capita, has median household consumption that is about 70 percent larger (and a relatively smaller 40 percent of the population below the $\$ 2$ poverty line). Fast-growing low-income countries Rwanda and Vietnam have relatively high measured GNI per capita given survey-measured median household consumption expenditure.

Figure 2 illustrates the relationship between median consumption and GDP per capita in simpler form. It mirrors Figure 1 but simply plots median household consumption expenditure and income against GDP per capita, now with both concepts measured in 2005 PPP dollars. As shown, a linear fit captures the relationship between survey-based consumption expenditure and GDP per capita reasonably well (with an estimated slope of 0.23 and an $\mathrm{R}^{2}$ of 0.73 ). But the dispersion around the linear fit increases with GDP per capita. At a survey-based median household consumption expenditure or income of $\$ 3$ per capita per day (or about $\$ 1,000$ a year), GDP per capita ranges from around $\$ 2,000$ for Cameroon to over $\$ 8,000$ for Saint Lucia. Similarly, at a given GDP per capita of about $\$ 6,000$, survey-based median household consumption per capita per day varies between just over $\$ 3$ in China and just over $\$ 9$ in Ukraine. We find similar patterns when comparing

\footnotetext{
${ }^{6}$ In the 1953 UN System of National Accounts (United Nations Department of Economic Affairs, 1953), GNI at market prices was called gross national product (GNP). With the 1993 revision of the system, GNI has become the generally accepted terminology (Commission of the European Communities et al., 1993, p. 55). This paper will use GNI throughout the text.

${ }^{7}$ Klugman, Rodriguez and Choi (2011) provide a comprehensive review of the HDI methodology. Pritchett (2010) points out that although the HDI "was intended to promote the importance of non-economic dimensions of human well-being [...] cross national variability [is] increasingly driven by GDP per capita (p. 1).

${ }^{8}$ Anand and Segal (2008) review and discuss the use of household final consumption expenditure and other national accounts categories as inputs to global inequality analysis. Ravallion (2003) compares private consumption expenditure (PCE) from the national accounts with survey-based estimates.
} 
survey-based medians to GNI and HFCE per capita. Table 2 presents ratios of the survey median and mean to all three national accounts estimates for selected countries with survey estimates for consumption expenditure; Table 3 shows the same for countries with income as welfare measure.

Figure 3 shows that the national accounts measures can be particularly misleading for lowincome countries. We plot country ratios of survey mean and median consumption expenditure to GDP per capita and other national accounts-based measures on the vertical axis; and GDP per capita on the horizontal axis. The solid lines show locally-weighted nonparametric regressions that fit a curve without imposing a functional form. ${ }^{9}$ For survey means (bottom row), we broadly confirm the findings of Deaton (2005), who finds a negative relationship between the ratio of survey to national accounts means on the one hand, and GDP per capita on the other hand, for the poorest countries in his sample. The problem is essentially the same for median (top row), i.e. there is considerable dispersion of the ratio for the poorest countries.

But: Apples to oranges. We know we are comparing apples to oranges. National accounts aggregates have different purposes and sources than household surveys; in addition, gross national income is in market exchange rate dollars, adjusted by a factor that controls for exchange-rate fluctuations, while the survey data are in constant PPP terms and reflect consumption for most countries. ${ }^{10}$ Our point is not to substitute household survey-based median consumption for traditional aggregate measures or for reporting on poverty, but to supplement these using a single simple measure that captures information on typical wellbeing at the country level (or for other aggregates and dimensions, e.g. gender, race, global) and can over time in any dimension capture some information about the distribution of the benefits of growth as well.

But: Are survey-based data not also problematic? Deaton (2005), in his detailed comparison of the merits of survey-based household data to national accounts aggregates as the bases for measuring poverty and trends in poverty, shows that the relationship between the ratio of survey-based consumption (income) and national accounts measures on the one hand, and (the log of) GDP per capita on the other hand, is not monotonic; it declines among lowincome countries (as in Figure 3 with more recent data), is stable among middle-income countries, and declines again among high-income countries. Based on data series from surveys and national accounts available in the early 2000s, he concludes there is a downward bias in measuring absolute consumption in the surveys, especially in low-income countries, and thus an upward bias in estimating their poverty rates. He argues that the national

\footnotetext{
9 This approach closely follows Deaton (2005), Figures 1 and 2, where he is comparing means from national accounts to survey means. Deaton also reports a negative relationship for the high-income countries, which we do not show, as we are using Povcal data which covers only the developing countries.

${ }^{10}$ For classifying countries into income groups and for other operational purposes, the World Bank uses an adapted GNI per capita calculation. See http://data.worldbank.org/about/country-classifications/world-bankatlas-method for more details (last accessed September 2013).
} 
accounts include items that are not consumed by the poor but are rapidly growing, so that growth in national consumption is likely to be faster than the growth of consumption of the poor. Assuming that the discrepancy between slower growth in surveys and faster growth in national accounts is not entirely due to a bias in national accounts, the growth in consumption of the poor and therefore the rate of poverty decline are likely understated.

We find similar discrepancies between measuring median consumption or income per capita and national accounts estimates. Figure 4 illustrates for four countries-listed in increasing order of GDP per capita - real growth rates of national accounts measures compared to mean and median consumption expenditure based on household surveys. In Uganda, the poorest country in our set, the survey-based estimates track national accounts measures relatively closely. In India, the growth of mean and median survey-based consumption expenditure significantly falls behind national accounts estimates, a long-standing empirical observation in the literature. ${ }^{11}$ In South Africa, the survey median tracks national accounts estimates relatively well, but survey mean does not. In Mexico, the richest country in the group where inequality measured by the Gini has fallen recently, ${ }^{12}$ real growth of survey estimates is higher than real growth of national accounts estimates.

There is no way to know the respective biases of the survey-based estimates of mean consumption and the national accounts estimates. Deaton concludes, however, that for understanding the relationship between growth and poverty reduction, "there is little choice but to use the surveys" (2005, p. 18), and adds that the emphasis ought to be on developing a set of international protocols for survey design. ${ }^{13}$

While the survey-based data are not perfect, in the long run they are likely to be a more convincing indicator of well-being at the household and individual level than any national accounts measures, particularly as standards for households surveys improve and they become more consistent across countries and over time within countries. As noted above, there has been considerable progress in improving survey design as well as in managing the resulting data, including in the last decade, driven by the demand for better measurement of absolute poverty and trends in poverty in relation to growth at the World Bank. ${ }^{14}$ Were the international community to resolve to estimate and report median consumption expenditure or income as a measure of well-being, and trends in median consumption expenditure or income as an indicator of changes in the distribution of well-being, that would add to the impetus to improve the quality of household survey data in general.

11 The discrepancy between survey and national accounts in India is empirically well-established, including in Srinivasan and Bardhan (1974), Datt and Ravallion (2002), and Deaton and Kozel (2005).

12 López-Calva and Lustig, eds. (2010).

13 Deaton concludes in the context of changes in the absolute well-being of people as related to changes in such aggregate measures as GDP per capita that if we are to "convince those who are skeptical of the idea that average growth reaches the poor, there is little choice but to use the surveys" (2005, p. 18).

14 For this the credit goes to the work of Ravallion and his colleagues at the World Bank. 


\subsection{The international poverty lines are too low in two respects}

The development community has relied for more than two decades on progress in reducing poverty (with the extreme poverty line now at $\$ 1.25$ a day, and the moderate poverty line at $\$ 2$ a day) as a key indicator of changing material well-being for the 5.7 billion people living in developing countries. But the $\$ 1.25$ and $\$ 2$ lines are too low as the principal measures of well-being, in at least two respects.

First, by design the international poverty lines were set at the average of the national poverty lines of 15 poor countries in the period from 1990 to 2005 (Ravallion et al., 2009). By 2000, 27 percent of the population in developing countries lived in countries where the national poverty line was $\$ 2$ or greater. ${ }^{15}$ Today 42 percent of developing country population lives in the upper-middle-income countries, where national poverty lines mostly exceed $\$ 2$; in Brazil, for example, eligibility for conditional cash transfers is set for households where per capita income is at about $\$ 2.20$ or below, and the median local moderate poverty line is $\$ 3.40$ a day. ${ }^{16}$

With continued growth in developing countries, national poverty lines will naturally increase in absolute terms. People care about their relative income status, as remarked by Adam Smith (1776) in his writing about social exclusion. He noted that a "creditable day-labourer would be ashamed to appear in public without a linen shirt, the want of which would be supposed to denote that disgraceful degree of poverty" (V.2.148). ${ }^{17}$ The idea of relative deprivation is commonly used to define poverty in rich countries and is embodied in the European Union's (EU) concept of being "at risk of poverty or social exclusion", which is defined as people living in households with less than 60 percent of the median household income in each of the EU's 28 member states. ${ }^{18}$

\footnotetext{
15 We use the compilation of national poverty lines from Ravallion et al. (2009, Table A1). They collect 75 national poverty lines for countries with valid PPP conversion factors, covering the years 1990 to 2005. Of those 75 lines, 38 are above $\$ 2$ a day. In the median survey year 2000, the complete set of 75 countries accounted for 92 percent of the total population in all low and middle-income countries and 73.8 percent of the global population, according to the World Bank classification.

16 Brazil does not have an official moderate poverty line (but an official extreme poverty line). The eligibility criterion for Brazil's flagship conditional cash transfer program Bolsa Familia at the time of writing was R $\$ 70$ of household income per capita per month. Assuming 2011 prices, this is approximately equal to $\$ 2.2$ per capita per day at 2005 PPP. Brazil's Institute of Applied Economic Research (IPEA) also provides regional moderate poverty lines (see http://www.ipeadata.gov.br/doc/LinhasPobrezaRegionais.xls, last accessed September 2013). The median line was R $\$ 192.2$ per capita per month at 2009 prices, or $\$ 3.4$ per capita per day at 2005 PPP.

17 Birdsall (2006) provides a more detailed argument for why relative income status matters more than ipso facto inequality. Also see Graham and Pettinato (2002) for a comprehensive overview of the literature on happiness and economic well-being. They demonstrate individual perceptions about current and future income relative to others to be an important determinant of life satisfaction.

18 The EU defines the poor as "the persons whose resources (material, cultural and social) are so limited as to exclude them from the minimum acceptable way of life in the Member State to which they belong", a definition that is largely inspired by work on relative deprivation by Peter Townsend $(1979,1987)$. The standard "at-risk-of-poverty" indicator is the EU's relative poverty line, which is set at 60 percent of the median national
} 
The established international poverty lines need not change, even as national poverty lines rise. They are meant after all to reflect an absolute measure of misery, and they allow progress in reducing misery to be reflected as the world does, indeed, become a better place (as in Pinker, 2011). It makes sense that the international extreme poverty line remains the same (corrected only for inflation etc.); ${ }^{19}$ the newest World Bank goal is to reduce extreme poverty at $\$ 1.25$ a day to 3 percent or less of the world population by 2030 (World Bank, 2013, p. 7). However it would also make sense for the World Bank and other major development actors to begin incorporating a complementary measure of well-being for the "typical" person in each developing country and in the developing world, at the country and developing world medians, that by definition reflects gains in material well-being for the entire bottom half of any country's distribution of consumption/income at a given moment and over time.

Second, the poverty "line" (even the moderate poverty line at \$2) is limited in the sense that it fails to take into account the relevance of income security as a fundamental component of material well-being. In Birdsall et al. (2013), we define households with a daily household income of $\$ 4$ to $\$ 10$ per capita as vulnerable "strugglers", building on Ferreira et al. (2012) and Lopez-Calva and Ortiz (2011). They are strugglers because they are income-insecure (consumption per capita would be about the same or lower; see Appendix A which compares income and consumption in Mexico, one of the few countries with household surveys of both). A reasonable degree of income security (associated with "middle class" status) would suggest a line of well-being closer to income of $\$ 10$ per capita per day at least for many middle-income developing countries. For China, India and low-income countries and for consumption, the escape from vulnerability might be lower, perhaps as low as $\$ 6$ per day. In Birdsall et al. (2013), on the basis of long-term growth forecasts and assuming no change in 2005 income distributions, we project median household income/consumption in developing countries to reach $\$ 6.50$ per capita per day in 2040 - notable progress but still leaving almost half of developing country populations income-insecure.

International measuring and reporting of country medians in the next several decades would have the advantage of providing annual information on the extent to which that projected change is occurring in countries, supplementing the absolute poverty lines with a measure reflecting the more ambitious and fulsome concept of well-being associated with a reasonable level of income security.

In one other fundamental sense $\$ 2$ is modest and $\$ 1.25$ even more so. In Bangladesh, at $\$ 2$ per capita per day, the estimated food share in total consumption is almost 60 percent. In rural China, where median consumption expenditure is still just over $\$ 2$ per capita per day,

\footnotetext{
household income (European Commission, 2012). Similarly, the OECD (2008) has defined as poor households that have an income below 50 percent of the median national household income.

19 Atkinson and Bourguignon (2001) and Ravallion and Chen (2011) argue for hybrid measures of absolute and relative poverty. Ravallion and Chen propose a "weakly relative poverty line" that has an absolute minimum of $\$ 1.25$ up to a mean consumption of $\$ 1.95$ a day, and then rises with a slope of $1: 3$ of the poverty line to mean consumption.
} 
estimated food shares for the median household are around 44 percent. ${ }^{20}$ This compares to an estimated food share of 15 percent for poor households in rich OECD countries (Pritchett and Spivack, 2013). The food shares in Bangladesh and rural China reflect greatly limited choices on other goods and services for one-half and more of households in these countries; they surely impose difficult and sometimes tragic choices on households between for example, critical health needs and schooling of children, particularly to the extent that health and other forms of social insurance are limited.

\subsection{Median consumption reflects well not only well-being of individuals but the state of development broadly defined}

For more than two decades, the development community has relied implicitly if not explicitly on two measures to mark progress in developing and transitional countries: reductions in the rate and number of people below the poverty line and increases in or GDP (or GNI) per capita. Because neither takes into account initial distribution of income or changes in the distributions, neither is an adequate representation either of differences across countries or changes within countries over time in individual welfare. As a single measure, median household consumption expenditure or income per capita is better, in part because it reflects both growth or not in GDP and changes in distribution.

Neither changes in poverty nor changes in growth of GDP per capita are particularly useful in an instrumental sense for study of the determinants and the dynamics of development change for households. Poverty reduction as it turns out relies on growth measured in terms of GDP per capita, so that there is a wide consensus among analysts that growth is necessary if not sufficient for "development". It follows that reductions in poverty as a result of growth provide little or no information on what kind or pattern of growth is povertyreducing (and inequality reducing more generally), let alone what policies and interventions contributed to poverty reduction either independently or interacting positively with growth.

Pritchett et al. (2010) argue that development is better seen as a modernization process across four realms: the polity, the economy, social relations, and public administration concepts that can be represented empirically by variables linked to policy and growth performance. Median income turns out to be associated with regulatory quality (a partial proxy for "public administration") and with "policies for social inclusion and equity"21, a

\footnotetext{
20 For Bangladesh, we use primary survey data from the Household Income and Expenditure Survey (HIES) 2010 and find that in households with monthly income per capita of Tk 1,750 to Tk 2,500 (or $\$ 1.70$ to $\$ 2.40$ per capita per day at $2005 \mathrm{PPP}$ ), mean food consumption accounted for 59.2 percent of total household consumption in 2009. For China, we use regression-based estimates as described in Pritchett and Spivack (2013).

21 We use the World Bank's annual Country Policy and Institutional Assessment (CPIA) score for to measure policies for social inclusion and equity at the country level. The assessment is used in the resource allocation process for the Bank's concessional lending window (IDA), and is calculated as a simple average of five indicators: gender equality, equity of public resource use, building human resources, social protection and labor, and policies and institutions for environmental sustainability.
} 
possibly proxy for Pritchett's "social relations". However, the association is not necessarily greater than for GNI per capita (Figure 5).

Finally, in addition to its merits in terms of simplicity and accessibility, the median is robust (for example to underreporting of income and consumption which tends to be relatively greater at higher incomes), and durable. It is durable in the sense that it is and will remain politically salient in middle-income countries where median income is already well above the $\$ 1.25$ line (e.g. Tunisia with median consumption expenditure at about $\$ 6.10$ a day, Mexico with median consumption expenditure at about $\$ 7$ a day, Malaysia with median income at about $\$ 9$ a day). In some of these middle-income countries, where extreme poverty using the international "line" at $\$ 1.25$ still exists, a group of "new poor" 22 above $\$ 1.25$ but below $\$ 10$ will constitute a much larger share of the population than the poor or the secure middle class for the next several decades, and a key political as well as social challenge will be whether and by how much their income grows, and by how much relative to those already better off. That brings us to our next section.

\section{The mean-to-median ratio as a simple measure of the distribution of material well-being}

The study of inequality has a long history in economics, and sustained increases in inequality in OECD countries ${ }^{23}$ and the "success" in Latin America over the last decade ${ }^{24}$ in tackling income inequality, combined with better and more widely available household survey data, have further revived interest in analyzing the distribution of well-being. The literature has proposed a wide range of summary measures of the complete distribution (such as the Gini coefficient or the Theil index) or ratios between the top and the bottom parts of the distribution. ${ }^{25}$

Here we do not aim to review the various conceptual concerns or discuss tradeoffs between different inequality measures, but simply suggest that the median, combined with a measure of average or mean well-being, provides a simple and reasonably good indicator of the extent to which the distribution of income or consumption expenditure (which turns out to be almost universally lognormal) is skewed to the right, and thus more or less concentrated (and

22 See Birdsall et al., 2013.

23 The OECD $(2008,2011)$ documents increasing income inequality in its member countries, particularly in English-speaking countries, some Scandinavian countries, and Israel. Corak (2013) focusses on rising income inequality in the United States, while Alvaredo et al. (2013) provide a historical perspective. Atkinson et al. (2011) provide a comprehensive review of a recent literature that is focusing on top incomes, mostly using income tax data.

24 Lustig et al. (2013) show that income inequality measured by the Gini coefficient declined in 13 of 17 Latin American countries between 2000 and 2010.

25 Atkinson (1970), Sen (1973), Foster and Sen (1997), and Cowell (2000) discuss various measures and their properties and provide a good overview of the vast literature. 
thus more or less unqual) above the median. ${ }^{26}$ In that sense the median combined with generally well-known means (for example in the form of changes in the mean associated with growth rates) can be said to be a "distribution-aware" measure.

A simple way of combining the mean with the median is to calculate a ratio between the two. ${ }^{27}$ This provides a simple measure of skewness of the distribution. ${ }^{28}$ Figure 6 plots the mean-to-median ratio for developing countries, using data from the most recent year (mostly between 2007 and 2011), against the Gini, arguably the most commonly used inequality measure. It shows the former has been a reasonably good indicator of the latter; both measures weight more heavily the middle of distributions than the extreme. Figure 7 plots an index of the ratio of the mean to the median consumption expenditure in comparison to indices of the Gini and two other measures: the ratio of the $90^{\text {th }}$ percentile to the $10^{\text {th }}$ percentile of the consumption distribution, and the "Palma index", which is defined as the ratio of the consumption or income share of the top 10 percent to the bottom 40 percent. ${ }^{29}$ Figure 8 again plots the same for countries in Latin America for which survey data are in income not consumption terms.

The ratio of the $90^{\text {th }}$ percentile to the $10^{\text {th }}$ percentile and somewhat less so the Palma index are obviously more sensitive to distributional changes at the top of distributions than the Gini and the mean-to-median ratio. The p90/p10 ratio, for example, is the only measure that picks up a slight decrease in Chilean inequality between the most recent two observations (Figure 8, panel d) and the only measure that picks up a slight increase in inequality in South Africa between the two most recent observations (Figure 7, panel c).

${ }^{26}$ Lopez and Serven (2014) demonstrate empirically using a large dataset of developing and high income countries that the observed distribution of per capita income and per capita consumption expenditure can be very closely approximated with a lognormal specification.

27 The ratio of the mean to the median (or, somewhat less intuitively in positively skewed income distributions, the ratio of the median to the mean) has long been used in the literature, including in political economy models of redistribution. Wolfson $(1994,1997)$ proposes a measure of "polarization", the degree to which observations move from the middle of the distribution to the tails, to quantify the decline in the "middle class". The ratio of the median to the mean is one component of his measure (in addition to the share of income held by the bottom half of the population). On the concept of polarization, also see Foster and Wolfson (2010). More recently, Aaberge and Atkinson (2013) have described how the median acts as a "watershed" for the way in which different income transfers have different effects on reducing poverty, inequality, and polarization.

${ }^{28}$ Graphically, the inverse of the mean-to-median ratio is the slope of the tangent to the Lorenz curve at the median. As Wolfson (1997, p. 408) points out, one can construct a distribution in which an equalizing (PigouDalton) transfer on one side of the median could theoretically move the Lorenz curve closer to the line of perfect equality and thus reduce the Gini coefficient, but leave the slope of the tangent at the median of the Lorenz curve unaffected. The ratio of the mean to median hence can be shown to violate the Pigou-Dalton principle, which requires that inequality rise in response to a (mean-preserving) transfer from a poorer to a richer person (Sen, 1973; Foster and Sen, 1997). By definition, the mean-to-median ratio also does not capture median- and meanpreserving transfers as in Aaberge and Atkinson (2013).

${ }^{29}$ Cobham and Sumner (2013). 
Overall, comparison of the different inequality measures illustrates the more fundamental point that none of them is "objective", and that each of them embodies some concept of social welfare.

The comparisons also illustrate an advantage and at the same time a disadvantage of the mean-to-median ratio compared to the other "ratio" measures. It is less sensitive to underreporting of income (and consumption expenditure) at the top of distributions (that is greater than elsewhere in the distributions); at the same time it will be less sensitive to underreporting and shifts in the extent of any underreporting than a measure based only on the top 10 percent, and thus more robust.

Publicly available anonymous tax data would solve the problems of measurement and underreporting at the top of distributions, as is now the case for the United States and several other advanced economies. ${ }^{30}$ But relatively few developing countries have income tax systems in the first place. Underreporting at the top in household surveys would not be a problem were we able to use means or averages from national accounts data, which will include for example, the kind of windfall oil and other natural resource income which historically is associated with greater concentrations of income. ${ }^{31}$ However as we discussed above, the relationship between household survey and national accounts measures of mean income (and consumption) varies across countries and over time in a way that makes it silly to combine means from the latter with the median from the former as a measure of anything.

\section{Measuring shared development progress}

In the previous two sections we argued that the median is a good indicator of typical material well-being across countries and over time, and that the ratio of the mean to the median can be used as a good indicator of the distribution of well-being. In this section, we present a third application of the median that measures change in well-being over time within countries (or other groups) independent of its initial absolute level and distribution. We argue that the change in the mean-to-median ratio can be an easily accessible post-2015 indicator of shared development progress. More specifically, we propose that the rate of increase in median consumption expenditure or income after taxes and transfers exceed the rate of increase in average consumption or income in the same period.

We have shown that the mean-to-median ratio tracks the Gini coefficient reasonably well as a measure of inequality at a point in time. The same is true for individual countries over time. Figure 9 plots median and mean consumption expenditure along with the Gini since 1980 for Uganda, India, South Africa and Mexico; and Figure 10 does the same for countries

\footnotetext{
${ }^{30}$ See Piketty and Saez (2003) for their study on the US. Atkinson et al. (2011) provide a recent summary. Country data from the recent literature is accessible online through the "World Top Incomes Database" (http://topincomes.g-mond.parisschoolofeconomics.eu, last accessed January 2014).

31 As in Acemoglu and Robinson (2012) and, for Latin America, Sokoloff and Engerman (2000).
} 
of Latin America where income is the indicator of material well-being. In these figures, the horizontal line at $\$ 3$ per capita per day (left axis) marks the approximate median income for the entire developing world population ${ }^{32}$ and at 0.4 (right axis) the approximate median Gini coefficient in the latest year of observation.

South Africa in panel (c) and Mexico in panel (d) of Figure 9 illustrate why the median in relation to the mean adds to understanding of the distributional impact of growth in the two countries: In South Africa, the median remained almost stagnant while the mean grew substantially. Inequality, as indicated by the Gini coefficient, meanwhile increased from an already high 0.59 in 1993 to 0.63 in 2009, the highest value in the sample. In Mexico, where inequality measured by the Gini coefficient has fallen from 0.52 in 1992 to 0.47 in 2010, the mean and the median both increased at similar rates. The same positive trend over the last decade can be seen in Brazil, Chile, and Peru.

Similarly, Figure 11 illustrates the change in the mean-to-median ratio for the United States and compares it to the change in the Gini coefficient. The left panel shows the stagnation of real median household income vis-à-vis real mean household income over the last four decades. Between 1975 and 2012, median household income increased by about 11.4 percent, while mean household income increased by about a third. In 2012, the mean income in the US was about 40 percent higher than median income. The mean-to-median ratio closely tracks the Gini coefficient over the same period, which increased from about 0.4 in 1976 to almost 0.48 in 2012.

Figure 12 illustrates the same point for South Africa and Mexico using growth incidence curves of household consumption expenditure since the early to mid 1990s. For each point in the initial consumption distribution, we calculate the real percentage change between the first and the last cross-section. The two different shapes tell a story of redistribution and declining inequality in Mexico compared to more unequal growth and increasing inequality in South Africa. The typical, i.e. median, household in South Africa gained much less than indicated by the average, i.e. mean, growth rate, which is mostly driven by the consumption growth at the top of the distribution (1.95 percent p.a. at the median compared to 3.42 percent p.a. at the mean). In Mexico, the typical household gained more than the average (1.86 percent p.a. at the median compared to 1.44 percent p.a. at the mean). ${ }^{33}$

Our proposed measure - the change in income or consumption expenditure at the median compared to the change in the mean - is closely related to the concept of shared prosperity, which the World Bank recently announced as a second organizational goal in addition to virtual elimination of extreme poverty; the Bank aims to "foster income growth of the

\footnotetext{
32 Based on calculations in Birdsall et al., 2013.

33 This is also reflected in Figure 4, in which we compare changes in survey medians and means to national accounts-based changes in means, using an index for each measure. Using these indices, median consumption has risen faster than GNI in Mexico, but slower than in South Africa - consistent with the growth incidence curves. But as noted above, we cannot be confident in the stability of the relationship between national accounts measures and survey measures over time, any more than across countries.
} 
bottom 40 percent of the population in every [developing] country." 34 Based on household survey data, the World Bank plans to measure and report the growth rate of mean income (or consumption) of the bottom 40 percent of the distribution, presumably then to compare it to the growth rate of mean income (or consumption) of the total population..$^{35}$

In Figure 13 we illustrate how the World Bank's shared prosperity indicator and our meanto-median approach perform against the Gini. In panel (a) we construct the World Bank indicator for a sample of 50 countries during the period from circa 1995 to 2010, again using data publicly available through the World Bank's PovcalNet website. Each observation is scaled according to the absolute change in the Gini coefficient in the same period where the color of the circle indicates the direction of the change (red circles indicate a country that has become more unequal, green circles indicate a country that has become more equal).

Panel (a) shows again as in the figures above impressive reductions in inequality e.g. in Brazil and Mexico and large increases in inequality in countries including China, South Africa, and India. In 26 out of 28 countries that saw a decrease in their Gini coefficient, growth for the bottom 40 percent of the population was faster than growth for the average of the population. Similarly, in 21 out of 22 countries that saw an increase in income inequality, growth for the bottom 40 percent was slower than growth for the population average. ${ }^{36}$ Against the benchmark of the Gini coefficient, the World Bank's indicator works well. Countries that are above the 45 degree line are "good" performers on shared development progress, and countries below the line are bad performers.

Panel (b) does the same exercise but this time for the change in the median compared to the change in the mean. It shows that there is not much difference between reporting on the growth in the mean consumption expenditure (income) of the bottom 40 percent on the one hand, and reporting the change in the mean-to-median ratio. Not surprisingly in this panel the countries cluster closer to the 45 degree line. However, it is still the case that in 26 out of the 28 countries that saw a decrease in income inequality, the average annual change of the median was greater than the average annual change of the population mean. In 18 out of 22 countries that saw an increase in income inequality, change of the median was less than the change of the mean. ${ }^{37}$

34 World Bank, 2013, p.7.

35 The Bank's approach is, perhaps by coincidence, related to the findings of Cobham and Sumner (2013), who based on an empirical observation by Gabriel Palma argue that the middle of the income distribution is much more stable over time than the bottom 40 percent and the top 10 percent of the distribution.

36 Vietnam and Mozambique are the only two cases in which the growth rate of the bottom 40 percent was slower than the growth rate of the population mean while the Gini coefficient decreased. Zambia is the only country in which the Gini coefficient indicated an increase in inequality while the growth rate of the bottom 40 percent was faster than the growth of the population mean.

${ }^{37}$ Azerbaijan and the Philippines are the only the countries in which the Gini coefficient indicated a reduction in inequality, but the growth rate of the median was slower than the growth rate of the mean. In Mauritania, Cambodia, Honduras, and Bolivia, the Gini coefficient increased but growth the median was faster than the growth of the mean. 
There are two advantages of the mean/median comparison over the growth of the bottom 40 percent, in addition to the former's simplicity and greater accessibility. First, it incorporates an explicit comparison of the change in income for the typical person at the median to the average change (tied to the well-understood growth of the economy). Second, it does not require a calculation of the total average growth rate for the bottom 40 percent from one period to the next, but simply a comparison of the change in income at the median at two points in time. Figure 14 illustrates that the two indicators track each other closely over time.

In addition to measuring the change at the median, we propose a second (maybe more ambitious) adjustment to the indicator: Median consumption expenditure or income should be measured after taxes and transfers. Recent work of Lustig and Higgins (2013)

demonstrates the feasibility of estimating the effects of taxes and transfers on households in different income and consumption categories and demonstrates the redistributive impact of the fiscal system. Measuring household-survey median consumption expenditure or income with respect to different consumption or income concepts ${ }^{38}$ not only takes into account the effect of the distributional pattern of growth in market terms, but also the additional effect of policy "effort" reflected in taxes and transfers.

Finally, we re-iterate our earlier point that the collection of reliable household survey data of consumption or income should continue to be a priority for the international development community. Panel (c) of Figure 13 illustrates for the same set of countries as above the difference between growth at the survey median and the growth of the mean, with the mean in this instance measured by the national accounts measure of GNI per capita growth. While the general pattern seems roughly comparable to panels (a) and (b), the dispersion again illustrates Deaton's earlier point that there is "little choice but to use the surveys".

\section{Conclusion: Survey-based measures as development indicators for a new era}

Neither reductions in the poverty rate and nor increases in GDP per capita are adequate to measure changes in material well-being for the typical person in most developing countries, or to measure development progress broadly conceived to include social and political modernization, as in Pritchett et al. (2010). ${ }^{39}$ Most of the world's extreme poor now live in countries like Brazil, China, India and Nigeria that are enjoying reasonable growth and have become "middle-income" countries ${ }^{40}$ with large and growing numbers of people in the

38 See Lustig and Higgins (2013) for a more technical overview.

39 Even the Human Development Index seems inadequate, though its popularity speaks to the interest in a broader measure. Cf. note 7 .

40 The World Bank currently defines low-income countries as those where per capita GNI is at or below $\$ 1,035$ a year, using the World Bank Atlas method. Cf. note 10 . 
"middle class". ${ }^{41}$ In many of those countries it is the actual or perceived concentration of income at the top that is viewed as unfair and unreasonable - and as a possible economic and political constraint to increasing the opportunities and incomes of those at the bottom. ${ }^{42}$ Attention to median income makes sense for these countries over the next several decades. In the long run those countries are likely to follow the United States, where there is frequent reference in the media to failure of median household income and median wages to rise in the last decade. ${ }^{43}$

Meanwhile rising inequality, including in the high-income countries, has become associated with "globalization", and popular resentment following the global financial crisis of 2008-09 of bankers and political insiders has put the idea of elite capture on the agenda. The Arab Spring, the recent protests in Brazil, Chile, and Turkey, and the "we are the 99 percent" encampments in the United States, all seem to reflect a deep concern that political systems are ridden with abuse by economic and political insiders at the top. In economic terms, the resentment reflects concern that insiders are holding on to rents and creating barriers to competition and to creative destruction. One apparent result: in the UN-sponsored consultations in more than 70 countries, a widespread people's constituency for including attention to inequality in the post- 2015 development framework. ${ }^{44}$

In this paper we propose a simple and easily understood measure of material well-being, and of change in material well-being of the "typical" person in developing countries, i.e. of the person or household who is at the median of the distribution of per capita consumption expenditure. We argue that this measure has three advantages: simplicity and accessibility, durability, and relevance as a broad reflection of the development as a modernization process.

We argue that

- median consumption per capita is for developing countries as good or better as a measure of material well-being as the poverty rate (and clearly better than GNI per capita) for countries or groups of people within countries, ${ }^{45}$ combining information on the poverty rate and the poverty gap while also reflecting well the level of development broadly conceived in social and political terms;

41 Birdsall, 2010; Sumner, 2012. As we will note below, we do not agree with the expansive definition of the "middle class" in the developing countries to include everyone above the international or national poverty line.

${ }^{42}$ Sumner, 2012.

${ }^{43}$ DeNavas-Walt et al. (2012) provide official estimates of the median household income by the US Census Bureau. Mishel and Gee (2012) demonstrate that median real hourly wages remained virtually stagnant between 1973 and 2011.

${ }^{44}$ Compare remarks by Rebeca Grynspan summarized here: http://www.cgdev.org/blog/whether-andhow-measure-inequality-post-2015 (last accessed September 26, 2013)

45 This follows the approach in the report of the high-level panel on the post-2015 development agenda (United Nations, 2013), which recommends "that indicators be disaggregated to allow targets to be measured in various dimensions, by gender, geography, age, and ethnicity" (p. 58). 
- is "good enough" as a measure of inequality, when compared to mean consumption per capita, capturing for all practical purposes information equivalent to widely used measures of inequality including the Gini coefficient;

- and is "good enough" as a measure of changes in inequality over time when change at the median is compared to the mean, capturing the same information as the new World Bank measure of "shared prosperity".

Compared to the typical measures, we argue that a focus on the median and on changes in material well-being at the median in not only good enough as outlined above but has at least three additional advantages. In contrast to the typical measures using a poverty line, it is durable i.e. it will have political salience in all developing countries, including the uppermiddle-income developing countries, even as average per capita income increases in the next several decades. It better reflects broader measures of development. And in contrast to the World Bank measure of shared prosperity, the median when compared to the mean reflects changes at the top of the distribution (and without imposing any prior about at what percentile at the top).

Our good enough measure relies heavily on availability from household surveys of data on consumption (or income, though we prefer consumption, see Appendix A), in PPP terms, and ideally if not at annual frequency then at least every few years. We applaud the work at the World Bank, the United Nations and other development institutions to support the collection and management of these data, particularly in low-income countries that can benefit from technical and financial support for collection and analysis of this basic data, and urge greater attention to making these data fully accessible to the research community. We hope that the post-2015 development framework includes attention to the logic of creating the global public good such data represent in permitting broader learning about the determinants and consequences of development broadly conceived. 


\section{Bibliography}

Aaberge, Rolf, and Anthony B. Atkinson. 2013. “The Median as Watershed”. Discussion Papers 749. Oslo: Statistics Norway, Research Department.

Acemoglu, Daron, and James A. Robinson. 2012. Why Nations Fail: The Origins of Power, Prosperity and Poverty. 1st ed. New York, NY: Crown Publishers.

Ahluwalia, Montek S., Nicholas G. Carter, and Hollis B. Chenery. 1979. "Growth and Poverty in Developing Countries." Journal of Development Economics 6 (3): 299-341.

Ahluwalia, Montek S., John H. Duloy, Graham Pyatt, and T. N. Srinivasan. 1980. "Who Benefits from Economic Development? Comment." American Economic Review 70 (1): 242-45.

Alvaredo, Facundo, Anthony B Atkinson, Thomas Piketty, and Emmanuel Saez. 2013. "The Top 1 Percent in International and Historical Perspective." Journal of Economic Perspectives 27 (3): 3-20.

Anand, Sudhir, and Paul Segal. 2008. "What Do We Know about Global Income Inequality?" Journal of Economic Literature 46 (1): 57-94.

Atkinson, Anthony B, Thomas Piketty, and Emmanuel Saez. 2011. "Top Incomes in the Long Run of History." Journal of Economic Literature 49 (1): 3-71.

Atkinson, Anthony B. 1970. "On the Measurement of Inequality." Journal of Economic Theory 2 (3): 244-263.

Atkinson, Anthony B., and François Bourguignon. 2001. "Poverty and Inclusion from a World Perspective." In Governance, Equity, and Global Markets: The Annual Bank Conference on Development Economics - Europe, edited by Joseph E. Stiglitz and Pierre-Alain Muet, 151-166. Oxford: Oxford University Press.

Attanasio, Orazio P., and Miguel Székely. 1999. "An Asset-Based Approach to the Analysis of Poverty in Latin America”. Working Paper 376. Washington, DC: Inter-American Development Bank.

Birdsall, Nancy. 2006. “The World Is Not Flat: Inequality and Injustice in Our Global Economy". WIDER Annual Lecture 9. Helsinki: UNU World Institute for Development Economics Research.

—. 2010. "The (Indispensable) Middle Class: Or, Why It's the Rich and the Rest, Not the Poor and the Rest". Working Paper 207. Washington, DC: Center for Global Development.

Birdsall, Nancy, Nora Lustig, and Christian J. Meyer. 2013. “The Strugglers: The New Poor in Latin America?” Working Paper 337. Washington, DC: Center for Global Development.

Chen, Shaohua, and Martin Ravallion. 2010. "The Developing World Is Poorer Than We Thought, but No Less Successful in the Fight Against Poverty.” The Quarterly Journal of Economics 125 (4): 1577-1625.

Cobham, Alex, and Andy P. Sumner. 2013. "Is It All About the Tails? The Palma Measure of Income Inequality”. Working Paper 343. Washington, DC: Center for Global Development. 
Commission of the European Communities, International Monetary Fund, Organisation for Economic Co-operation and Development, United Nations, and World Bank. 1993. System of National Accounts 1993. System of National Accounts. Brussels/Luxembourg, New York, Paris, Washington DC.

Corak, Miles. 2013. "Income Inequality, Equality of Opportunity, and Intergenerational Mobility." Journal of Economic Perspectives 27 (3): 79-102.

Cowell, Frank A. 2000. "Measurement of Inequality." In Handbook of Income Distribution, edited by Anthony B. Atkinson and François Bourguignon, 1:87-166. Handbooks in Economics 16. Amsterdam: Elsevier.

Datt, Gaurav, and Martin Ravallion. 2002. "Is India's Economic Growth Leaving the Poor Behind?” Policy Research Working Paper 2846. Washington, DC: The World Bank.

Deaton, Angus. 2005. "Measuring Poverty in a Growing World (or Measuring Growth in a Poor World)." The Review of Economics and Statistics 87 (1): 1-19.

Deaton, Angus, and Margaret Grosh. 2000. “Consumption.” In Designing Household Survey Questionnaires for Developing Countries: Lessons from 15 Years of the Living Standards Measurement Study, edited by Margaret Grosh and Paul Glewwe, 1:91-133. Washington, DC: The World Bank.

Deaton, Angus, and Valerie Kozel. 2005. "Data and Dogma: The Great Indian Poverty Debate.” The World Bank Research Observer 20 (2): 177-199.

Deaton, Angus, and John Muellbauer. 1980. Economics and Consumer Behavior. New York, NY: Cambridge University Press.

Deaton, Angus, and Salman Zaidi. 2002. "Guidelines for Constructing Consumption Aggregates for Welfare Analysis”. Living Standards Measurement Study (LSMS) Working Paper 135. Washington, DC: The World Bank.

Deininger, Klaus, and Lyn Squire. 1996. "A New Data Set Measuring Income Inequality." World Bank Economic Review 10 (3): 565-91.

—. 1998. "New Ways of Looking at Old Issues: Inequality and Growth.” Journal of Development Economics 57 (2): 259-287.

DeNavas-Walt, Carmen, Bernadette D. Proctor, and Jessica C. Smith. 2012. Income, Poverty, and Health Insurance Coverage in the United States: 2011. Current Population Reports P60243. Washington, DC: US Government Printing Office.

European Commission. 2012. Measuring Material Deprivation in the EU: Indicators for the Whole Population and Child-Specific Indicators. 2012th ed. Eurostat Methodologies and Working Papers. Luxembourg: Publications Office of the European Union.

Ferreira, Francisco H. G., Julian Messina, Jamele Rigolini, Luis-Felipe López-Calva, Maria Ana Lugo, and Renos Vakis. 2012. Economic Mobility and the Rise of the Latin American Middle Class. Washington, DC: The World Bank.

Fields, Gary S. 1977. "Who Benefits from Economic Development? A Reexamination of Brazilian Growth in the 1960's." American Economic Review 67 (4): 570-82.

Foster, James E., and Michael C. Wolfson. 2010. "Polarization and the Decline of the Middle Class: Canada and the U.S." The Journal of Economic Inequality 8 (2): 247-273.

Foster, James, and Amartya Sen. 1997. On Economic Inequality. Expanded edition. Oxford: Oxford University Press. 
Graham, Carol, and Stefano Pettinato. 2002. Happiness and Hardship: Opportunity and Insecurity in New Market Economies. Washington, DC: Brookings Institution Press.

Independent Evaluation Group. 2011. "Marrakech Action Plan for Statistics, Partnership in Statistics for Development in the 21st Century, Trust Fund for Statistical Capacity Building”. Global Program Review, Volume 5, Issue 3. Washington, DC: The World Bank Group.

Instituto Nacional de Estadística y Geografía (INEGI). 2013a. Encuesta Nacional de Ingresos Y Gastos de Los Hogares (ENIGH) 2012: Nueva Construcción de Ingresos Y Gastos. Diseño Conceptual Y Definición de Categorías Y V ariables. Aguascalientes: Instituto Nacional de Estadística y Geografía.

—_. 2013b. "Encuesta Nacional de Ingresos Y Gastos de Los Hogares (ENIGH) 2012". Boletín de Prensa 278/13. Aguascalientes: Instituto Nacional de Estadística y Geografía. http://www.inegi.org.mx/inegi/contenidos/espanol/prensa/boletines/boletin/Comuni cados/Especiales/2013/Julio/comunica5.pdf.

Inter-American Development Bank. 1999. Facing Up to Inequality in Latin America. Economic and Social Progress Report (IPES) 1998/1999. Baltimore, MD: Johns Hopkins University Press.

Klugman, Jeni, Francisco Rodríguez, and Hyung-Jin Choi. 2011. “The HDI 2010: New Controversies, Old Critiques.” Journal of Economic Inequality 9 (2): 249-288.

Londoño, Juan Luis, and Miguel Székely. 1997. "Persistent Poverty and Excess Inequality: Latin America, 1970-1995”. Working Paper 357. Washington, DC: Inter-American Development Bank.

Lopez, Humberto, and Luis Serven. 2014. "A Normal Relationship? Poverty, Growth, and Inequality." Annals of Economics and Finance 15 (2): 593-624.

López-Calva, Luis F., and Eduardo Ortiz-Juarez. 2011. "A Vulnerability Approach to the Definition of the Middle Class". Policy Research Working Paper Series 5902. Washington, DC: The World Bank.

López-Calva, Luis Felipe, and Nora Lustig, ed. 2010. Declining Inequality in Latin America: A Decade of Progress? New York, NY and Washington, DC: United Nations Development Programm and Brookings Institution Press.

Lustig, Nora, and Sean Higgins. 2013. "Commitment to Equity Assessment (CEQ): Estimating the Incidence of Social Spending, Subsidies and Taxes: Handbook". CEQ Working Paper 1 (Revised Version September 2013). New Orleans, LA: Tulane University.

Lustig, Nora, Luis F. Lopez-Calva, and Eduardo Ortiz-Juarez. 2013. "Declining Inequality in Latin America in the 2000s: The Cases of Argentina, Brazil, and Mexico." World Development 44 (April): 129-141.

Mishel, Lawrence, and Kar-Fai Gee. 2012. "Why Aren't Workers Benefiting from Labour Productivity Growth in the United States?" International Productivity Monitor 23 (Spring 2012): 31-43.

Organisation for Economic Co-operation and Development (OECD). 2008. Growing Unequal? Income Distribution and Poverty in OECD Countries. Paris: OECD Publishing.

—. 2011. Divided We Stand: Why Inequality Keeps Rising. Paris: OECD Publishing. 
Piketty, Thomas, and Emmanuel Saez. 2003. "Income Inequality In The United States, 19131998." The Quarterly Journal of Economics 118 (1): 1-39.

Pinker, Steven. 2011. The Better Angels of Our Nature: Why Violence Has Declined. New York, NY: Viking Penguin.

Pritchett, Lant. 2003. "Who Is Not Poor? Proposing a Higher International Standard for Poverty”. Working Paper 33. Washington, DC: Center for Global Development.

—. 2010. "Birth Satisfaction Units (BSU): Measuring Cross-National Dierences in Human Well-Being". Human Development Research Papers 2010/03. New York, NY: United Nations Development Programme.

Pritchett, Lant, and Marla Spivack. 2013. "Estimating Income/Expenditure Differences Across Populations: New Fun with Old Engel's Law”. Working Paper 339. Washington, DC: Center for Global Development.

Pritchett, Lant, Michael Woolcock, and Matt Andrews. 2010. "Capability Traps? The Mechanisms of Persistent Implementation Failure”. Working Paper 234. Washington, DC: Center for Global Development.

Ravallion, Martin. 2003. "Measuring Aggregate Welfare in Developing Countries: How Well Do National Accounts and Surveys Agree?” The Review of Economics and Statistics 85 (3): $645-652$.

- 2012. "Why Don't We See Poverty Convergence?" American Economic Review 102 (1): $504-523$.

Ravallion, Martin, and Shaohua Chen. 2011. "Weakly Relative Poverty.” Review of Economics and Statistics 93 (4): 1251-1261.

Ravallion, Martin, Shaohua Chen, and Prem Sangraula. 2009. "Dollar a Day Revisited." World Bank Economic Review 23 (2): 163-184.

Sen, Amartya. 1973. On Economic Inequality. Oxford: Oxford University Press.

Smith, Adam. 1776. An Inquiry into the Nature and Causes of the Wealth of Nations. Vol. 2. London: W. Strahan and T. Cadell.

Sokoloff, Kenneth L, and Stanley L Engerman. 2000. "Institutions, Factor Endowments, and Paths of Development in the New World." Journal of Economic Perspectives 14 (3): 217 232. doi:10.1257/jep.14.3.217.

Srinivasan, T. N., and Pranab K. Bardhan. 1974. Poverty and Income Distribution in India. Calcutta: Statistical Publishing Society.

Sumner, Andy. 2012. “The Buoyant Billions: How 'Middle Class' Are the New Middle Classes in Developing Countries? (And Why Does It Matter?)”. Working Paper 309. Washington, DC: Center for Global Development.

Townsend, Peter. 1979. Poverty in the United Kingdom: A Survey of Household Resources and Standards of Living. Harmondsworth: Penguin Books.

—. 1987. "Deprivation.” Journal of Social Policy 16 (02): 125-146.

United Nations. 2013. A New Global Partnership: Eradicate Poverty and Transform Economies Through Sustainable Development. The Report of the High-Level Panel of Eminent Persons on the Post-2015 Development Agenda. New York, NY: United Nations.

United Nations Department of Economic Affairs. 1953. A System of National Accounts and Supporting Tables. Studies in Methods 2. New York, NY: United Nations. 
Wolfson, Michael C. 1994. "When Inequalities Diverge." American Economic Review 84 (2, Papers and Proceedings of the Hundred and Sixth Annual Meeting of the American Economic Association): 353-58.

- 1997. "Divergent Inequalities: Theory and Empirical Results." Review of Income and Wealth 43 (4): 401-421.

World Bank. 2013. “The World Bank Group Goals: End Extreme Poverty and Promote Shared Prosperity". Washington, DC: The World Bank. http://www.worldbank.org/content/dam/Worldbank/document/WB-goals2013.pdf. 
Table 1: Survey consumption expenditure and poverty (selected countries with median $<\$ 2$ a day, ca. 2010)

\begin{tabular}{|c|c|c|c|c|c|}
\hline \multirow{2}{*}{ Country } & \multirow{2}{*}{$\begin{array}{l}\text { Median household consumption } \\
\text { expenditure, per capita per day }\end{array}$} & \multicolumn{2}{|c|}{ Poverty headcount (percent) } & \multicolumn{2}{|c|}{ Poverty gap (percent) } \\
\hline & & PL at $\$ 1.25$ a day & PL at $\$ 2$ a day & PL at $\$ 1.25$ a day & PL at $\$ 2$ a day \\
\hline Zambia & 0.65 & 74.45 & 86.64 & 41.91 & 56.76 \\
\hline Nigeria & 1.16 & 54.37 & 78.47 & 21.84 & 39.17 \\
\hline Mali & 1.24 & 50.43 & 78.66 & 16.36 & 35.20 \\
\hline India (Rural) & 1.49 & 34.28 & 73.51 & 7.53 & 25.84 \\
\hline Swaziland & 1.56 & 40.63 & 60.40 & 16.00 & 29.26 \\
\hline Ethiopia & 1.63 & 30.65 & 66.00 & 8.19 & 23.64 \\
\hline India (Urban) & 1.77 & 28.93 & 57.59 & 7.39 & 21.23 \\
\hline Nepal & 1.81 & 24.82 & 57.25 & 5.55 & 19.04 \\
\hline
\end{tabular}

Note: $\quad$ Consumption expenditure in constant 2005 PPP dollar, per capita, per day. Countries are listed in ascending order of median consumption expenditure. Latest observation available from PovcalNet.

Source: $\quad$ Authors' calculations, based World Bank PovcalNet. 
Table 2: Survey consumption expenditure and national accounts (selected countries, ca. 2009)

\begin{tabular}{|c|c|c|c|c|c|c|c|c|c|c|c|c|c|c|c|c|}
\hline \multirow[b]{3}{*}{ Country } & \multirow[b]{3}{*}{ Region } & \multicolumn{6}{|c|}{ Survey-based welfare measure } & \multicolumn{3}{|c|}{ National accounts } & \multicolumn{6}{|c|}{ Ratios of survey mean and median to national account means } \\
\hline & & \multicolumn{6}{|c|}{ Household consumption expenditure } & \multirow{2}{*}{$\begin{array}{l}\text { GDP } \\
\text { mean }\end{array}$} & \multirow{2}{*}{$\begin{array}{l}\text { GNI } \\
\text { mean }\end{array}$} & \multirow{2}{*}{$\begin{array}{l}\text { HFCE } \\
\text { mean }\end{array}$} & \multirow{2}{*}{$\frac{\text { svy median }}{\text { GDP }}$} & \multirow{2}{*}{$\frac{\text { svy mean }}{\text { GDP }}$} & \multirow{2}{*}{$\frac{\text { svy median }}{\text { GNI }}$} & \multirow{2}{*}{$\frac{\text { svy mean }}{\text { GNI }}$} & \multirow{2}{*}{$\frac{\text { svy median }}{\text { HFCE }}$} & \multirow{2}{*}{$\frac{\text { svy mean }}{\text { HFCE }}$} \\
\hline & & median & mean & Gini & $\mathrm{p} 75 / \mathrm{p} 25$ & $\mathrm{p} 90 / \mathrm{p} 10$ & Palma & & & & & & & & & \\
\hline Uganda & Sub-Saharan Africa & 561 & 774 & 0.41 & 2.49 & 5.78 & 1.99 & 1,104 & 936 & 809 & 0.51 & 0.70 & 0.60 & 0.83 & 0.69 & 0.96 \\
\hline Ghana & Sub-Saharan Africa & 706 & 962 & 0.43 & 2.74 & 7.03 & 2.18 & 1,268 & & & 0.56 & 0.76 & & & & \\
\hline Kenya & Sub-Saharan Africa & 520 & 768 & 0.46 & 2.87 & 7.63 & 2.64 & 1,340 & 1,340 & 1,010 & 0.39 & 0.57 & 0.39 & 0.57 & 0.51 & 0.76 \\
\hline Bangladesh & South Asia & 497 & 620 & 0.32 & 1.99 & 3.74 & 1.28 & 1,464 & & 1,046 & 0.34 & 0.42 & & & 0.47 & 0.59 \\
\hline Nigeria & Sub-Saharan Africa & 422 & 553 & 0.40 & 2.61 & 6.39 & 1.85 & 2,213 & & & 0.19 & 0.25 & & & & \\
\hline Pakistan & South Asia & 645 & 789 & 0.30 & 1.86 & 3.30 & 1.16 & 2,323 & 2,368 & 1,628 & 0.28 & 0.34 & 0.27 & 0.33 & 0.40 & 0.48 \\
\hline India & South Asia & 565 & 724 & 0.34 & 1.96 & 3.75 & 1.39 & 3,122 & 3,088 & 1,805 & 0.18 & 0.23 & 0.18 & 0.23 & 0.31 & 0.40 \\
\hline Morocco & Middle East \& North Africa & 1,400 & 1,901 & 0.40 & 2.36 & 5.17 & 1.86 & 3,845 & 3,796 & 2,214 & 0.36 & 0.49 & 0.37 & 0.50 & 0.63 & 0.86 \\
\hline Egypt & Middle East \& North Africa & 1,117 & 1,341 & 0.29 & 1.84 & 3.23 & 1.11 & 5,412 & 5,453 & 3,801 & 0.21 & 0.25 & 0.20 & 0.25 & 0.29 & 0.35 \\
\hline China & East Asia \& Pacific & 1,226 & 1,758 & 0.45 & 3.16 & 8.17 & 2.43 & 6,207 & 6,214 & 2,249 & 0.20 & 0.28 & 0.20 & 0.28 & 0.55 & 0.78 \\
\hline South Africa & Sub-Saharan Africa & 1,233 & 3,082 & 0.63 & 4.81 & 17.11 & 7.05 & 9,357 & 9,143 & 5,967 & 0.13 & 0.33 & 0.13 & 0.34 & 0.21 & 0.52 \\
\hline Mexico & Latin America \& Caribbean & 2,569 & 3,656 & 0.47 & 2.88 & 7.70 & 2.72 & 11,979 & 11,852 & 7,964 & 0.21 & 0.31 & 0.22 & 0.31 & 0.32 & 0.46 \\
\hline Turkey & Europe \& Central Asia & 2,667 & 3,438 & 0.40 & 2.63 & 6.55 & 1.87 & 12,671 & 12,549 & 8,910 & 0.21 & 0.27 & 0.21 & 0.27 & 0.30 & 0.39 \\
\hline Russia & Europe \& Central Asia & 3,944 & 5,358 & 0.40 & 2.51 & 5.80 & 1.90 & 13,616 & 13,178 & 8,009 & 0.29 & 0.39 & 0.30 & 0.41 & 0.49 & 0.67 \\
\hline Poland & Europe \& Central Asia & 3,720 & 4,495 & 0.33 & 2.15 & 4.28 & 1.28 & 17,959 & & & 0.21 & 0.25 & & & & \\
\hline
\end{tabular}

Note: All figures are in constant 2005 PPP dollar, per capita, annual. Countries are listed in ascending order of GDP per capita. Latest observation available from PovcalNet.

Source: Authors' calculations, based International Comparisons Project, World Bank World Development Indicators, World Bank PovcalNet. 
Table 3: Survey income and national accounts (selected countries, ca. 2009)

\begin{tabular}{|c|c|c|c|c|c|c|c|c|c|c|c|c|c|c|c|c|}
\hline \multirow[b]{2}{*}{ Country } & \multirow[b]{2}{*}{ Region } & \multirow{2}{*}{\multicolumn{6}{|c|}{$\frac{\text { Survey-based welfare measure }}{\text { Household consumption expenditure }}$}} & \multicolumn{3}{|c|}{ National accounts } & \multicolumn{6}{|c|}{$\underline{\text { Ratios of survey mean, median to nat. account means }}$} \\
\hline & & & & & & & & $\begin{array}{l}\text { GDP } \\
\text { mean }\end{array}$ & $\begin{array}{l}\mathrm{GNI} \\
\text { mean }\end{array}$ & $\begin{array}{l}\text { HFCE } \\
\text { mean }\end{array}$ & $\frac{\text { svy median }}{\text { GDP }}$ & $\frac{\text { svy mean }}{\text { GDP }}$ & $\frac{\text { svy median }}{\text { GNI }}$ & $\frac{\text { svy mean }}{\text { GNI }}$ & $\frac{\text { svy median }}{\text { HFCE }}$ & $\frac{\mathrm{svy} \text { mean }}{\text { HFCE }}$ \\
\hline Honduras & Latin America \& Caribbean & 1,363 & 2,429 & 0.57 & 4.62 & 19.99 & 5.19 & 3,484 & 3,337 & 2,607 & 0.39 & 0.70 & 0.41 & 0.73 & 0.52 & 0.93 \\
\hline Colombia & Latin America \& Caribbean & 1,866 & 3,366 & 0.56 & 3.59 & 12.92 & 4.50 & 8,450 & 8,078 & 5,549 & 0.22 & 0.40 & 0.23 & 0.42 & 0.34 & 0.61 \\
\hline Peru & Latin America \& Caribbean & 2,155 & 3,184 & 0.48 & 3.39 & 9.98 & 2.94 & 8,504 & 7,853 & 5,410 & 0.25 & 0.37 & 0.27 & 0.41 & 0.40 & 0.59 \\
\hline Brazil & Latin America \& Caribbean & 2,579 & 4,366 & 0.55 & 3.54 & 12.82 & 4.32 & 9,456 & 9,267 & 6,071 & 0.27 & 0.46 & 0.28 & 0.47 & 0.42 & 0.72 \\
\hline Costa Rica & Latin America \& Caribbean & 2,971 & 4,868 & 0.51 & 3.20 & 9.81 & 3.33 & 10,110 & 9,800 & 6,819 & 0.29 & 0.48 & 0.30 & 0.50 & 0.44 & 0.71 \\
\hline Venezuela & Latin America \& Caribbean & 1,896 & 2,630 & 0.45 & 2.92 & 8.37 & 2.41 & 10,658 & 10,629 & 5,236 & 0.18 & 0.25 & 0.18 & 0.25 & 0.36 & 0.50 \\
\hline Malaysia & East Asia \& Pacific & 3,268 & 4,797 & 0.46 & 3.21 & 9.13 & 2.63 & 13,072 & 12,802 & 6,416 & 0.25 & 0.37 & 0.26 & 0.37 & 0.51 & 0.75 \\
\hline Chile & Latin America \& Caribbean & 3,450 & 5,921 & 0.52 & 2.87 & 8.44 & 3.50 & 13,784 & 12,856 & 8,503 & 0.25 & 0.43 & 0.27 & 0.46 & 0.41 & 0.70 \\
\hline
\end{tabular}

Note: $\quad$ All figures are in constant 2005 PPP dollar, per capita, annual. Countries are listed in ascending order of GDP per capita. Latest observation available from PovcalNet.

Source: $\quad$ Authors' calculations, based International Comparisons Project, World Bank World Development Indicators, World Bank PovcalNet. 
Figure 1: Survey median consumption expenditure, international poverty line and rate, and GNI per capita (latest year available)

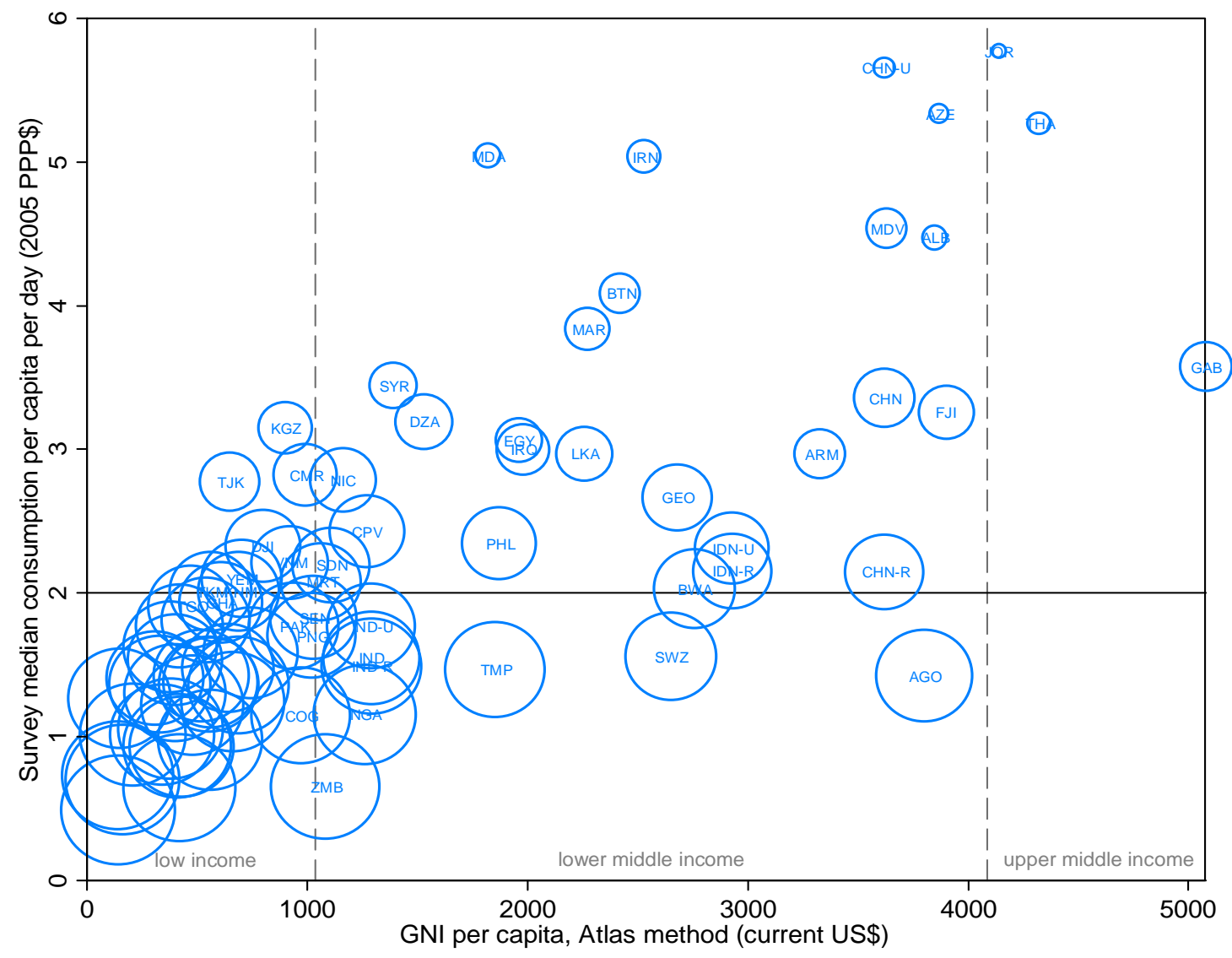

Note: $\quad$ Circles are scaled according to the population share living below \$2 per capita per day at 2005 PPP. Dashed lines mark current (September 2013) World Bank country income groups: low income, \$1,035 or less; lower middle income, $\$ 1,036-\$ 4,085$.

Source: Authors' calculations, based on International Comparisons Project, World Bank World Development Indicators, World Bank PovcalNet. 
Figure 2: Survey median consumption expenditure and income, GDP per capita, and linear fit (latest year available)

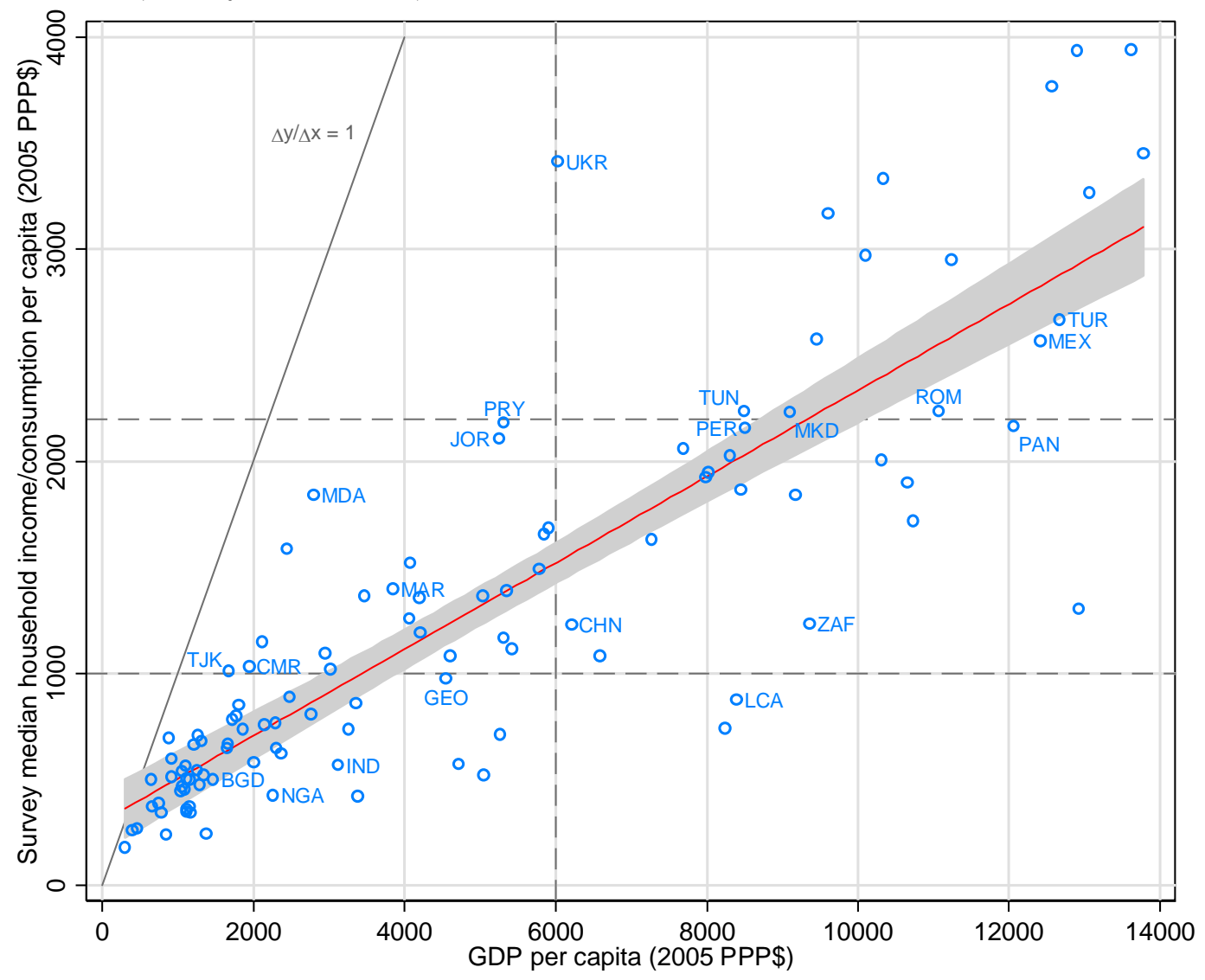

Note: $\quad$ Line shows a linear fit $(\mathrm{Y}=230.7+0.227 *$ GDP; $\mathrm{R} 2=0.73)$.

Source: Authors' calculations, based on International Comparisons Project, World Bank World Development Indicators, World Bank PovcalNet. 
Figure 3: Ratios of survey mean and median consumption expenditure to national accounts vs. GDP per capita (latest year available)
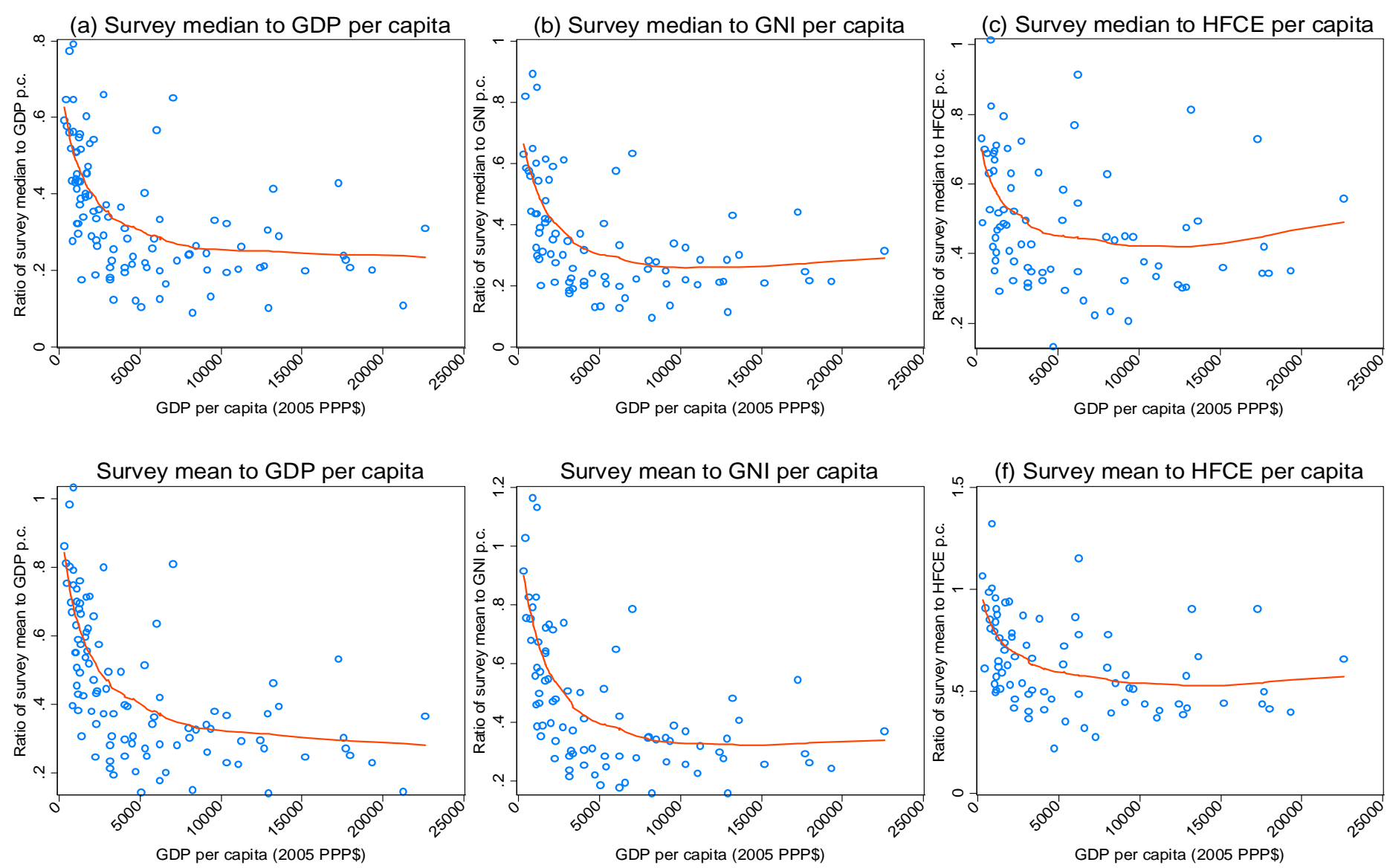

Note: $\quad$ Line shows locally-weighted regressions with bandwidth 1.5; our approach closely follows Deaton (2005, p. 6).

Source: Authors' calculations, based on International Comparisons Project, World Bank World Development Indicators, World Bank PovcalNet. 
Figure 4: Real growth of survey consumption expenditure and national accounts (selected countries, over time)
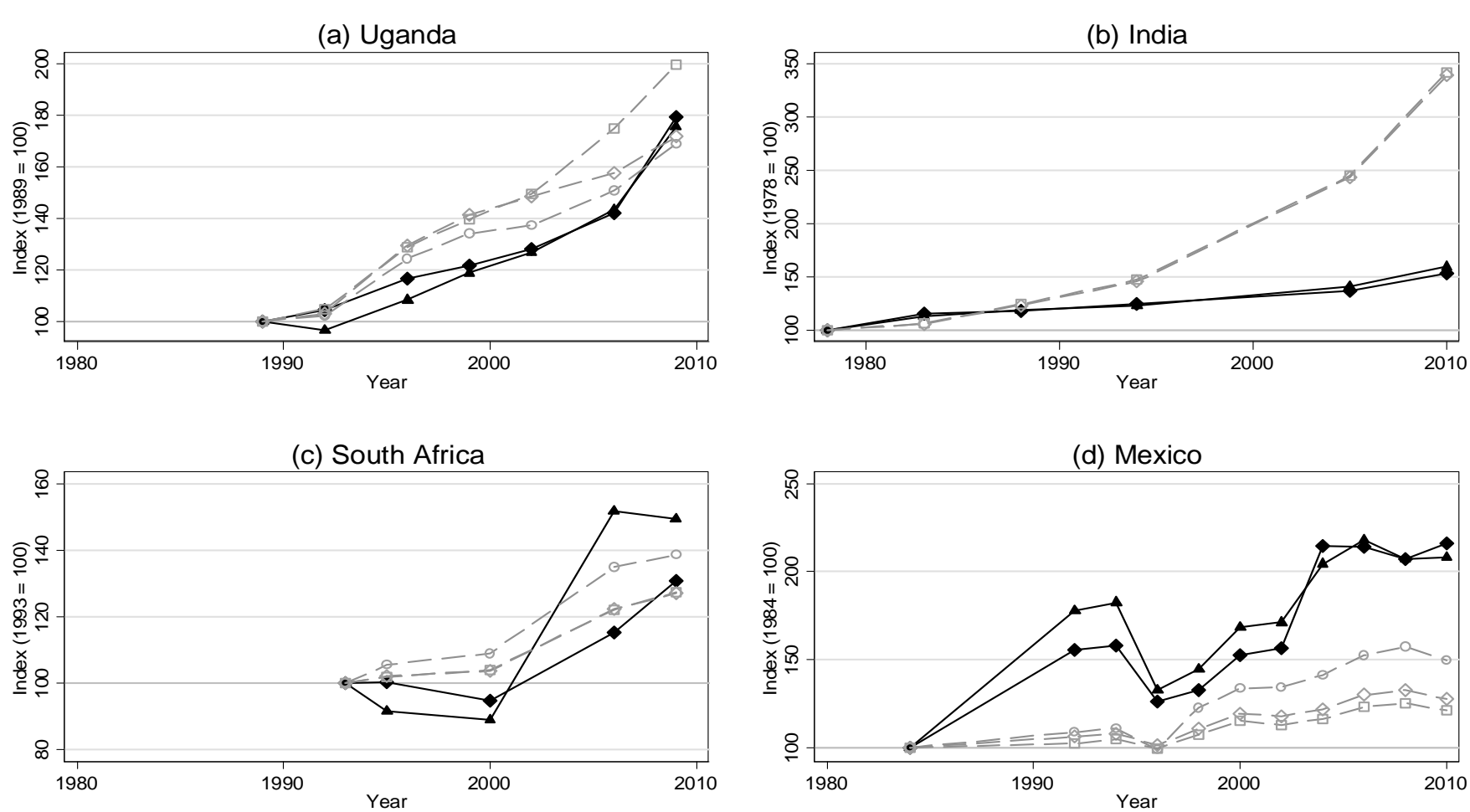

$\begin{array}{ll}\longrightarrow \text { Survey: Median } & -\neg-- \text { National accounts: GDP } \\ \longrightarrow & -\checkmark-- \text { National accounts: GNI } \\ & -\multimap-- \text { National accounts: HFCE }\end{array}$

Source: Authors' calculations, based on International Comparisons Project, World Bank World Development Indicators, World Bank PovcalNet. 
Figure 5: Survey median consumption expenditure per capita per day vs. social and governance indicators (latest year available)
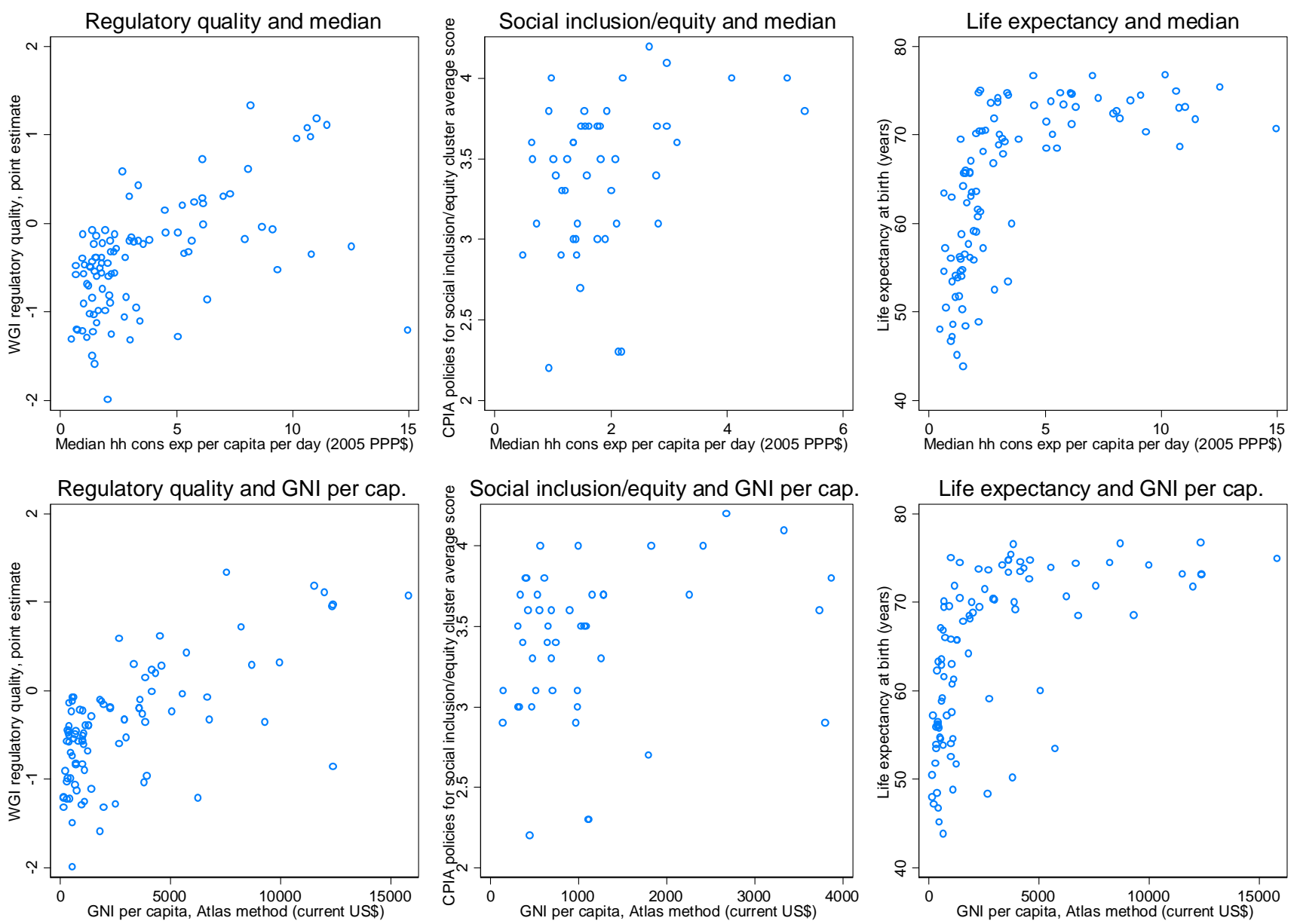

Source: Authors' calculations, based on International Development Association, World Bank World Development Indicators, Worldwide Governance Indicators. 
Figure 6: Ratio of survey consumption expenditure or income mean to median vs. Gini coefficient (latest year available)

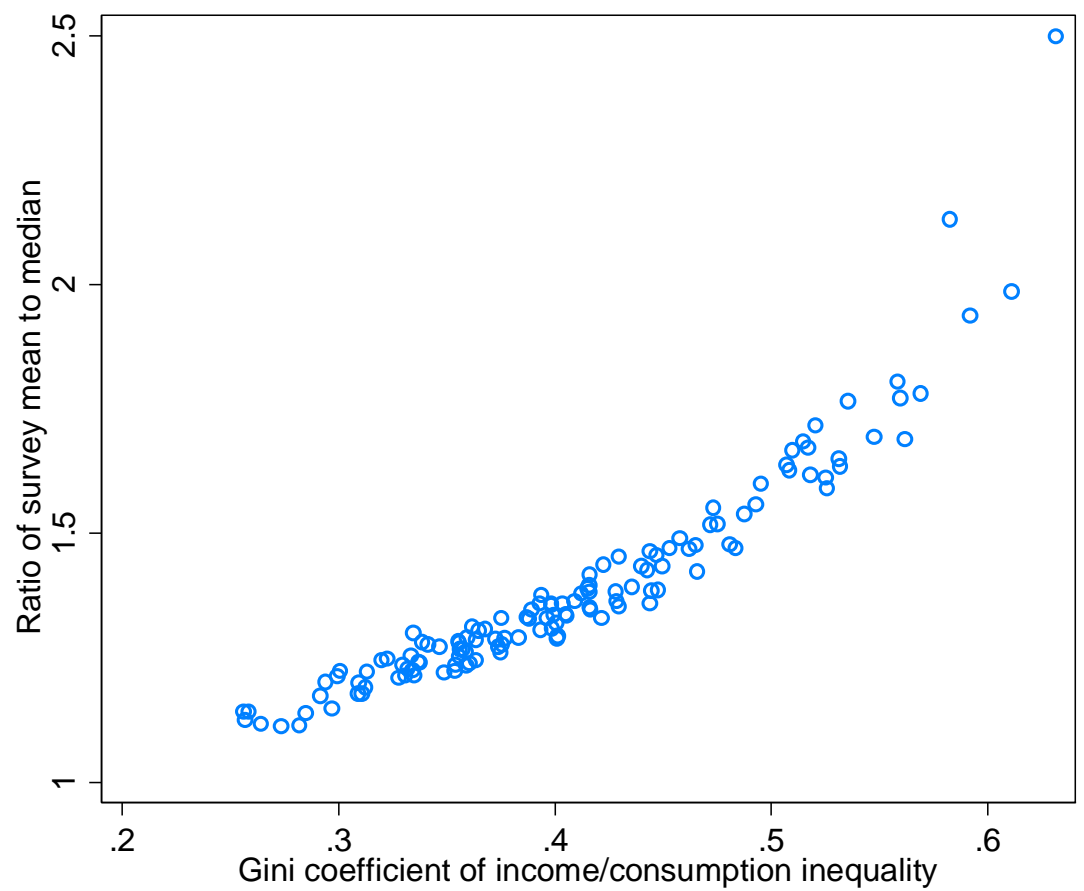

Source: Authors' calculations, based on International Comparisons Project, World Bank World Development Indicators, World Bank PovcalNet. 
Figure 7: Survey measures of consumption expenditure inequality (selected countries, over time)
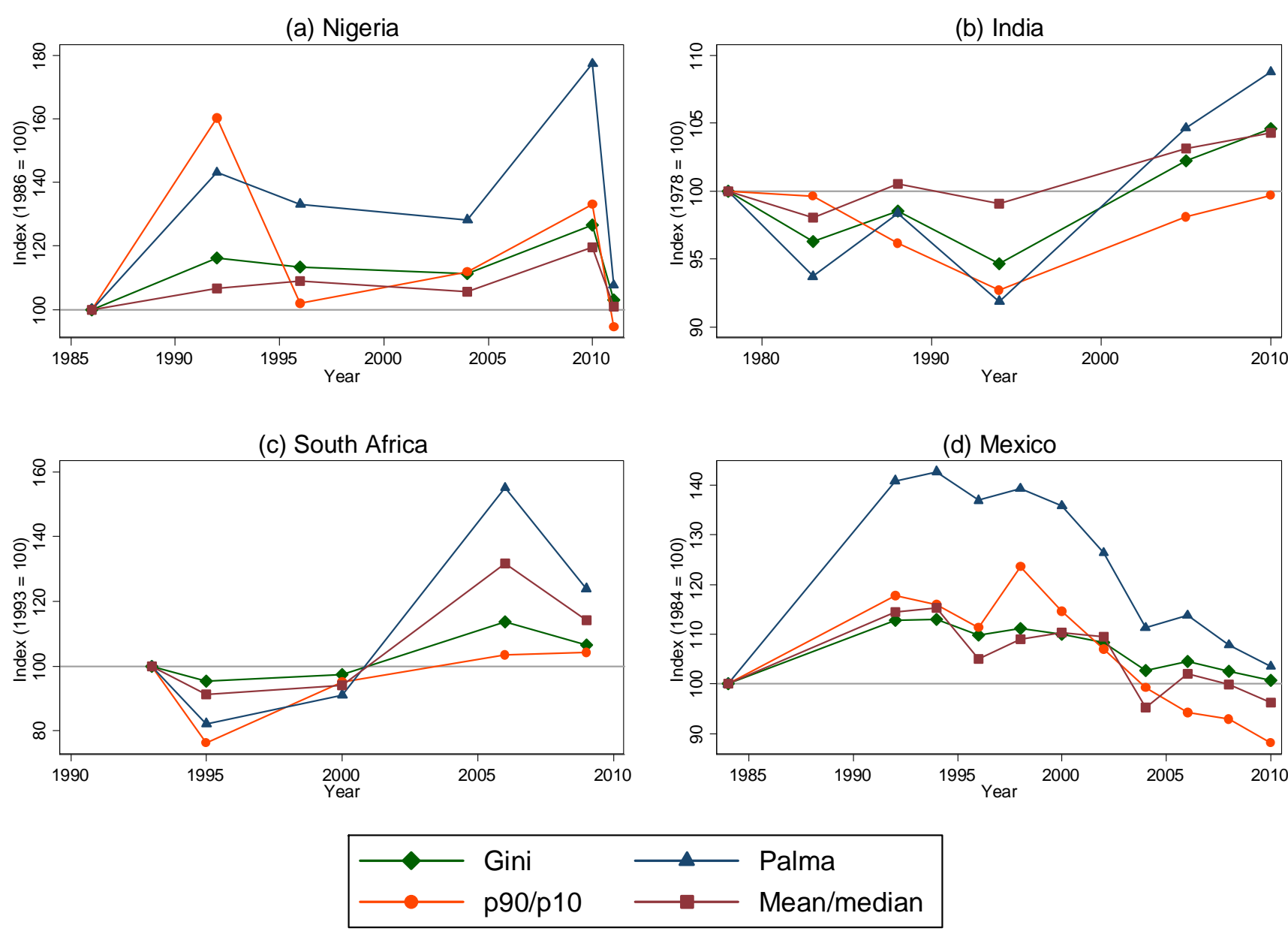

Source: $\quad$ Authors' calculations, based on World Bank PovcalNet. 
Figure 8: Survey measures of income inequality (selected countries, over time)
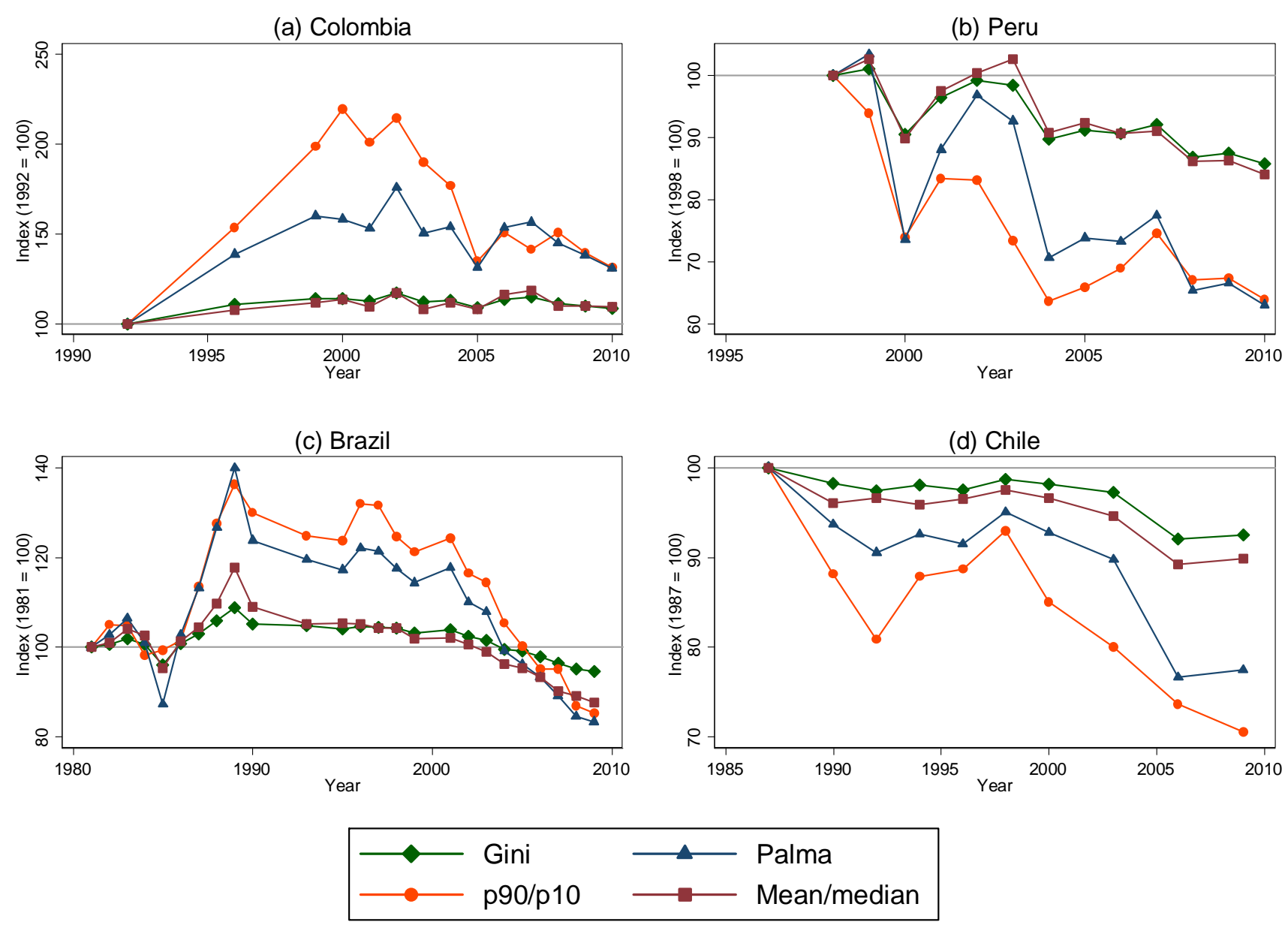

Source: Authors' calculations, based on World Bank PovcalNet. 
Figure 9: Survey mean and median consumption expenditure and Gini coefficient (selected countries, over time)
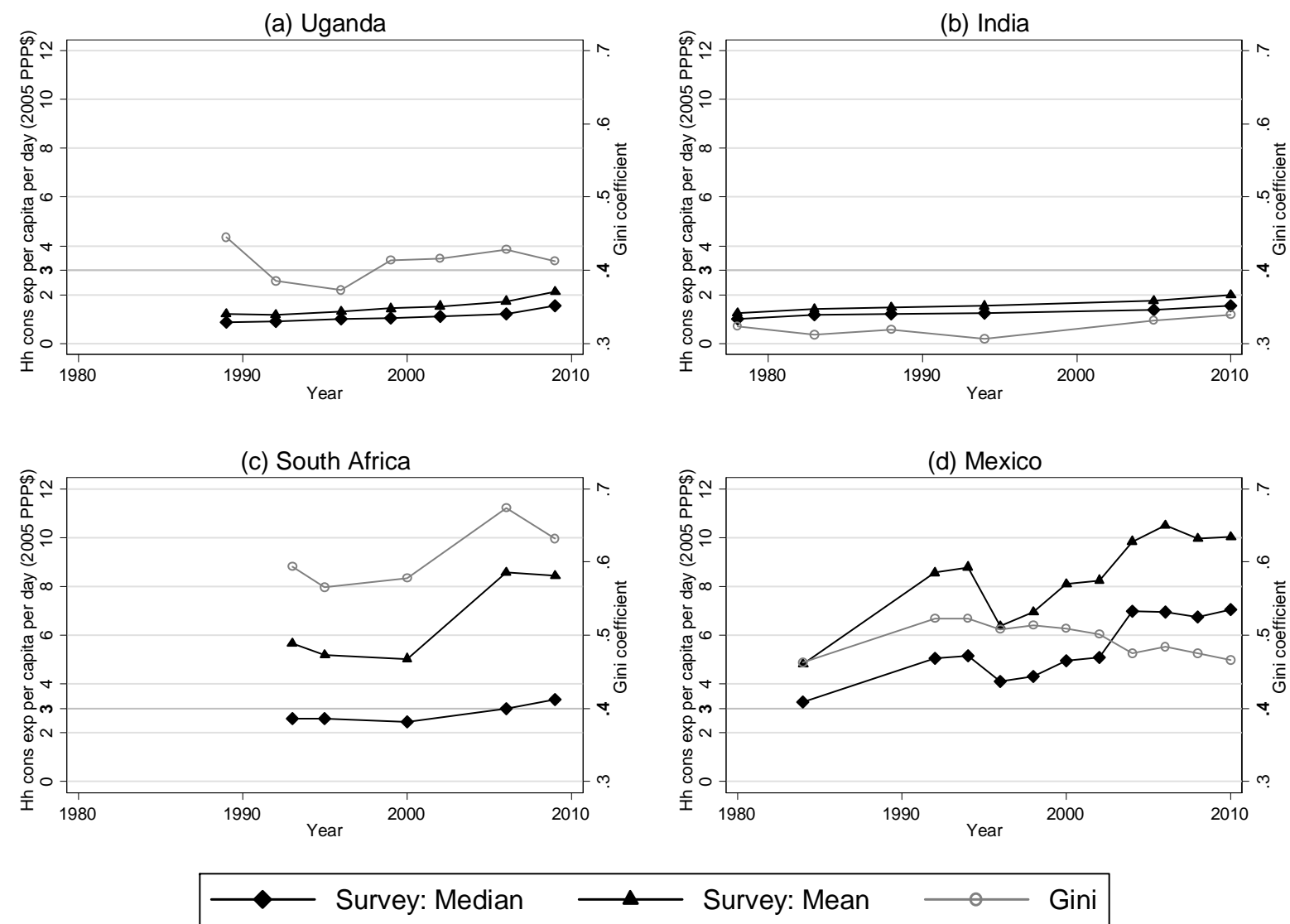

Note: Grey horizontal line marks $\$ 3$ per capita per day and a Gini coefficient of 0.4 . We estimate $\$ 3$ per capita per day to be the median household income/consumption expenditure in developing countries in 2010 (Birdsall et al., 2013). A Gini coefficient of 0.4 roughly represents the median Gini coefficients in the latest year of observation, based on data from World Bank PovcalNet.

Source: $\quad$ Authors' calculations, based on World Bank PovcalNet. 
Figure 10: Survey mean and median income and Gini coefficient (selected countries, over time)
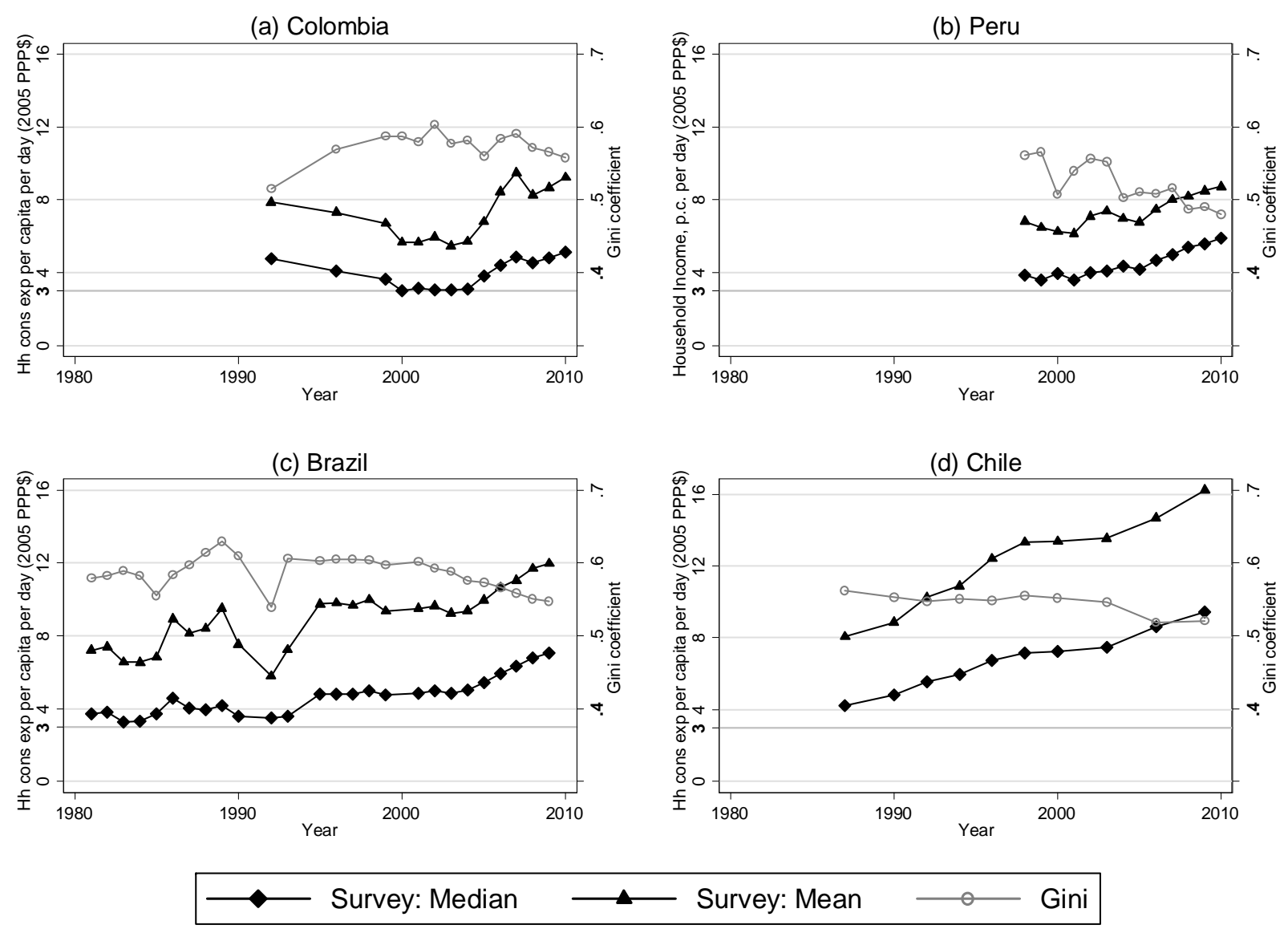

Note: Grey horizontal line marks $\$ 3$ per capita per day and a Gini coefficient of 0.4 . We estimate $\$ 3$ per capita per day to be the median household income/consumption expenditure in developing countries in 2010 (Birdsall et al., 2013). A Gini coefficient of 0.4 roughly represents the median Gini coefficients in the latest year of observation.

Source: $\quad$ Authors' calculations, based on World Bank PovcalNet. 
Figure 11: Real household income and household income inequality in the United States (1976 to 2012)
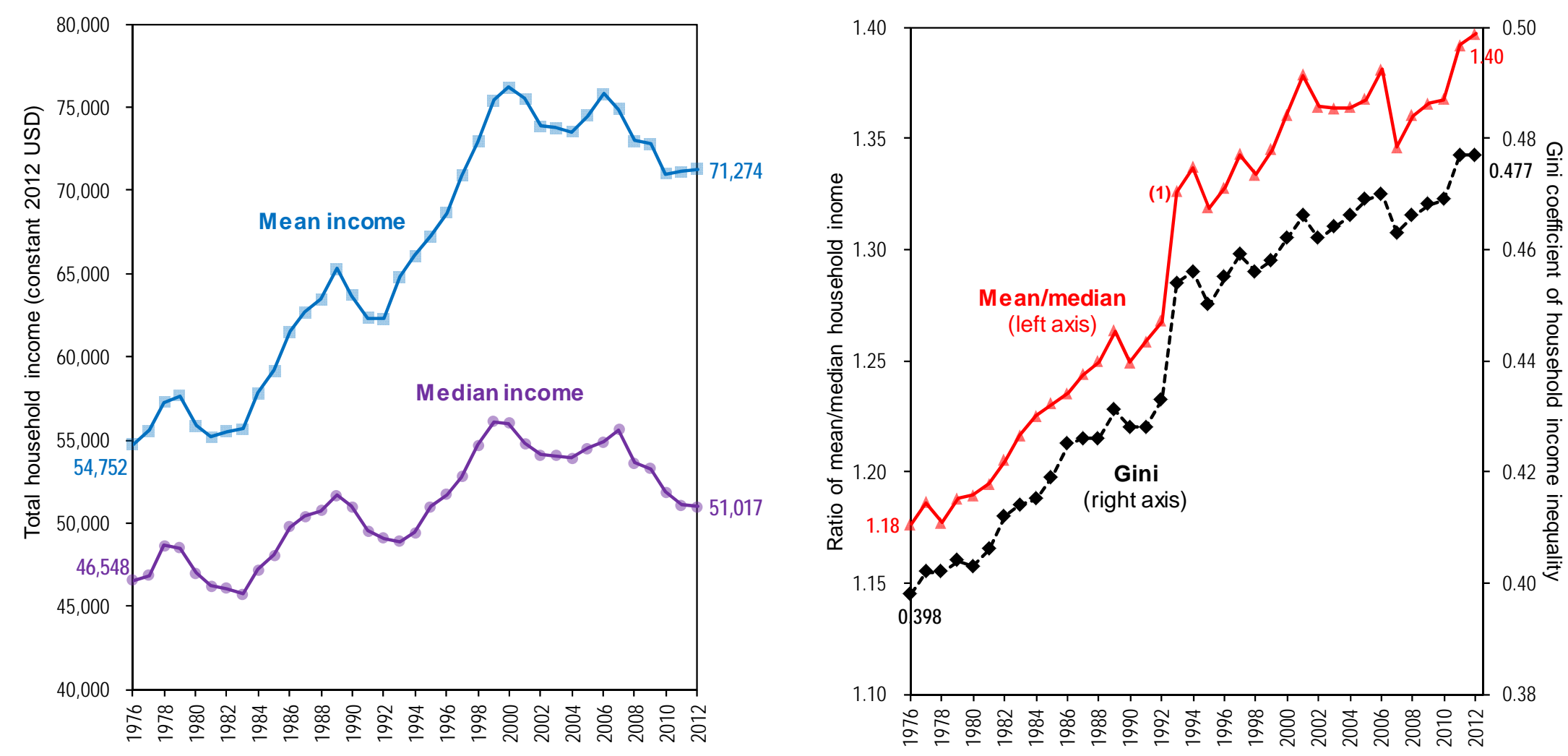

Note: Income is total household money income, measured in constant 2012 USD, deflated using the CPI-U-RS index. Data collection method changed from paper and pencil to computer-assisted interviewing. In addition, the March 1994 income supplement was revised to allow for the coding of different income amounts on selected questionnaire items.

Source: Authors' calculations, based on U.S. Census Bureau, Current Population Survey, Annual Social and Economic Supplements. 
Figure 12: Growth incidence curves of survey consumption expenditure (South Africa and Mexico, circa 1995 to 2010)
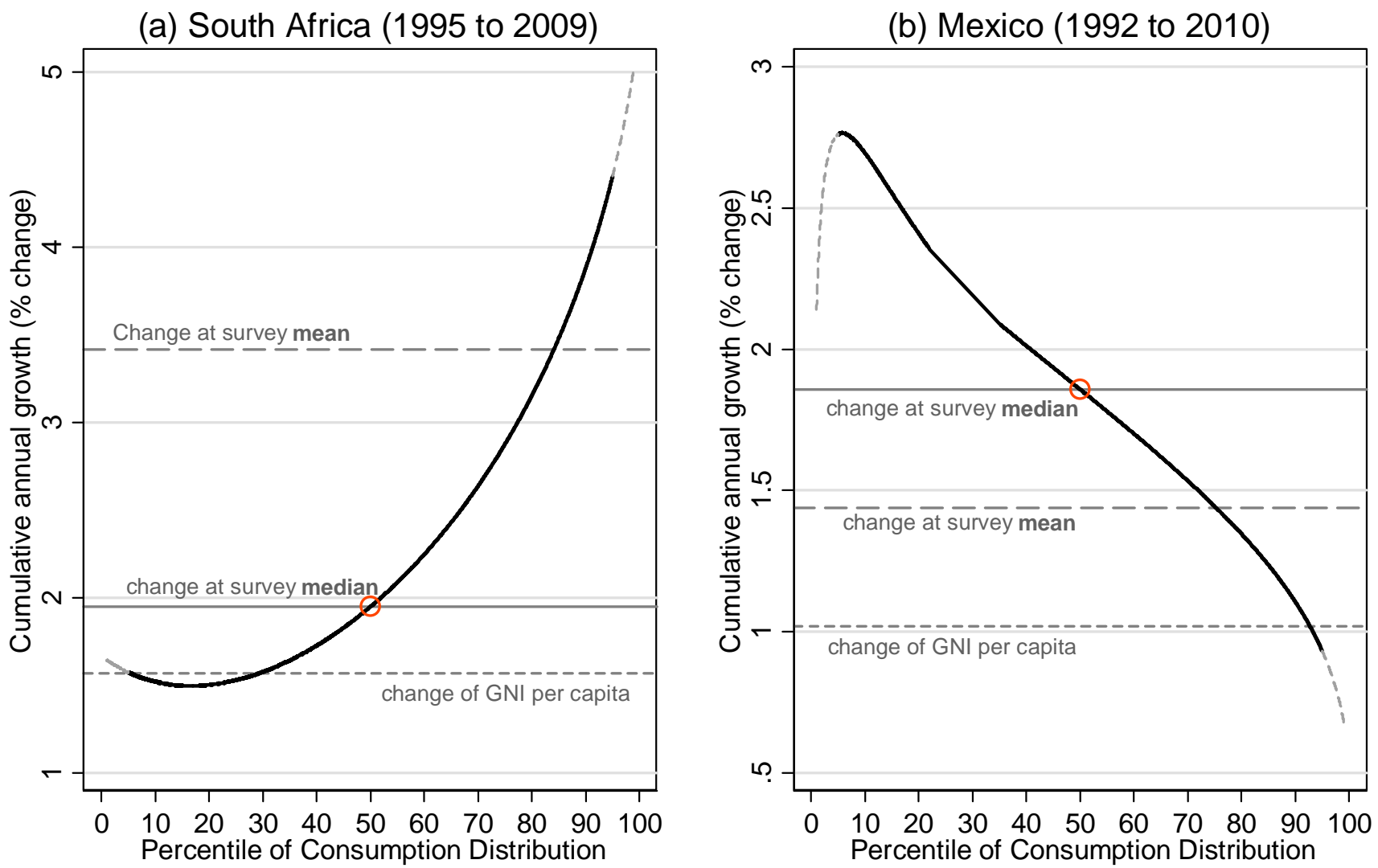

Note: We suspect that the estimated growth rates at the top and bottom tails of the distribution are not fully reliable. We hence show the top and bottom 5 percent as dashed grey lines. The curve for Mexico in 2010 exported from the World Bank's PovcalNet appears to have a kink at the $25^{\text {th }}$ percentile. While this does not affect our results, we linearly interpolate the curve at this point for illustrative purposes.

Source: $\quad$ Authors' calculations, based on World Bank World Development Indicators, World Bank PovcalNet. 
Figure 13: World Bank shared prosperity indicator, change of median compared to change of mean, and change of median to change of GNI per capita (selected countries, circa 1995 to 2010)

(a) World Bank Shared Prosperity Indicator

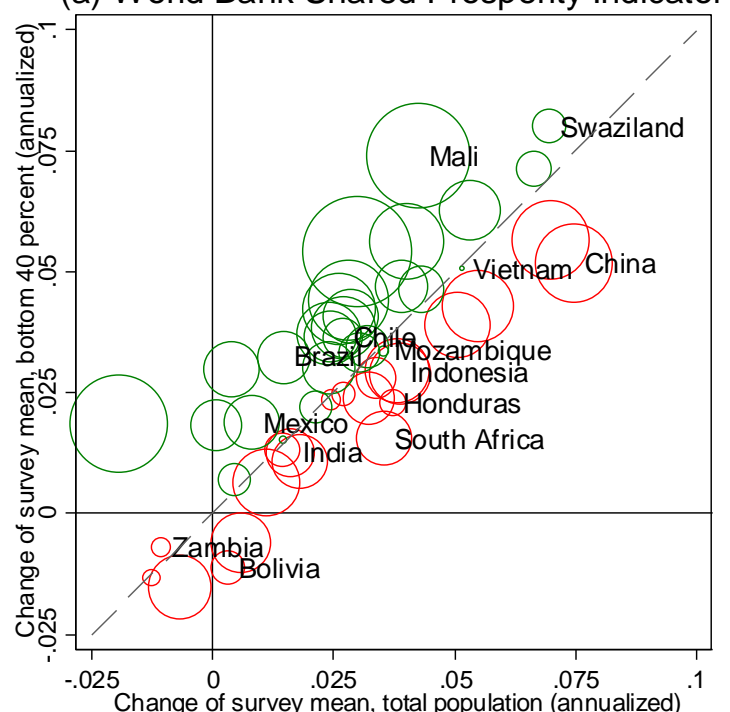

(b) Change of median vs. change of mean

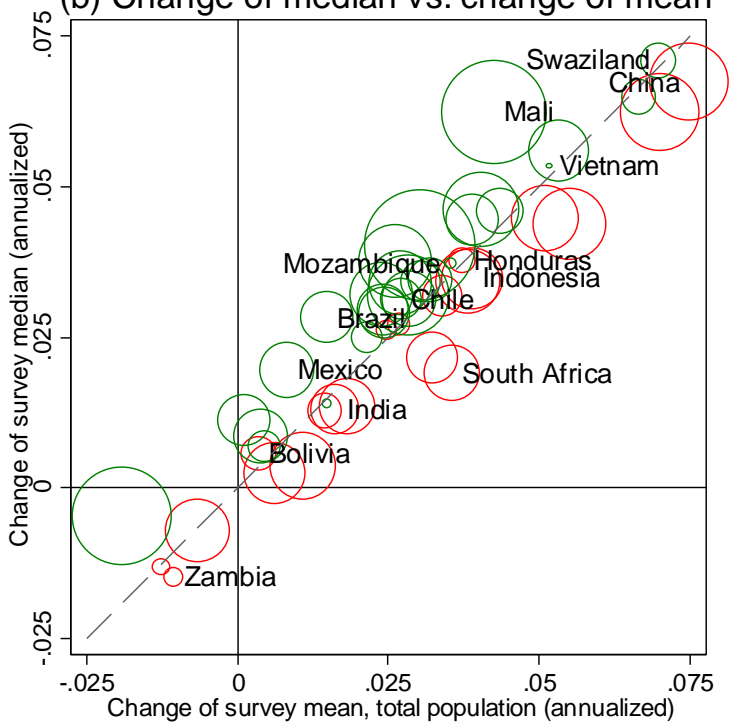

(c) Change of median vs. change of GNI pc

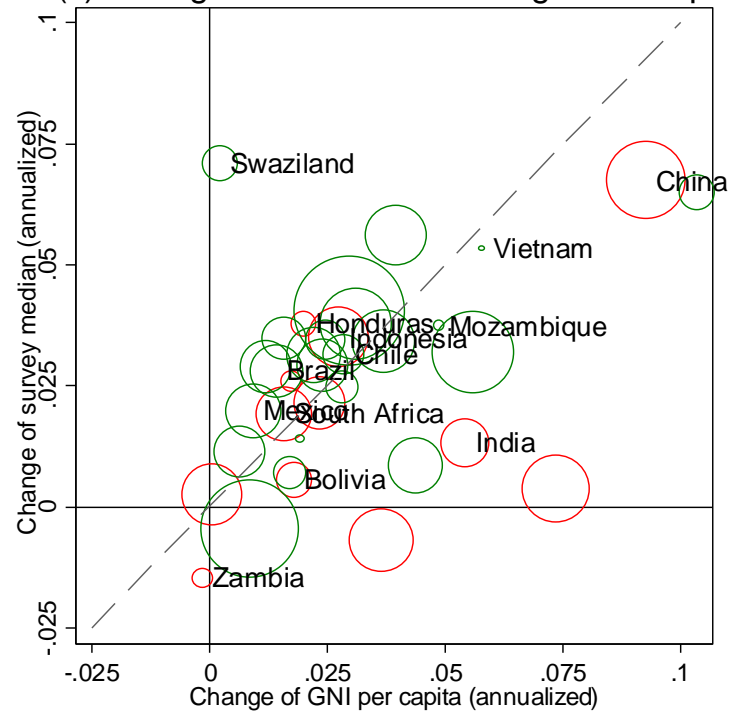

Note: $\quad$ Circle size represents the change in the Gini coefficient over the same period. Red circles mark negative changes (increase in inequality), green circles mark positive changes (decreases in inequality). All changes are compound annual growth rates between circa 1995 and 2010.

Source: $\quad$ Authors' calculations, based on World Bank World Development Indicators, World Bank PovcalNet. 
Figure 14: Survey consumption expenditure median and mean of the bottom 40 percent (selected countries, over time)
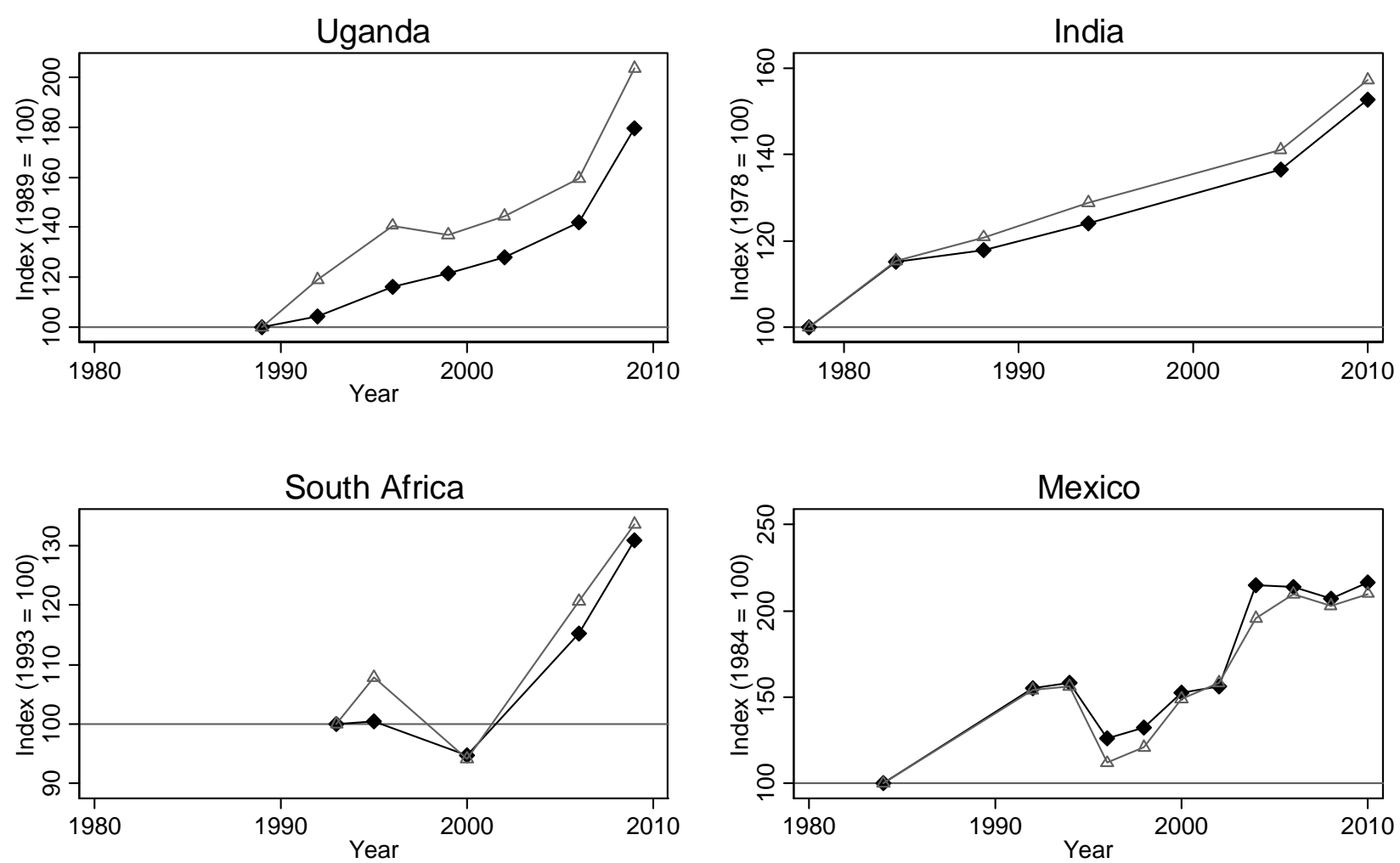

\section{$\sim$ Population median $\triangle \triangle$ Mean of bottom 40 percent}

Source: Authors' calculations, based on World Bank PovcalNet. 


\section{Appendix A: Comparing household survey-based income and consumption expenditure}

Throughout the text, we abstract from the question of whether to measure material wellbeing using household consumption expenditure or income. We prefer consumption primarily because it is closer to material well-being at any one point in time for a household, and because it is likely to be closer to permanent income than current (measured) income. ${ }^{46}$

But some countries, including Malaysia and many countries in Latin America and the Caribbean, ${ }^{47}$ have frequent and comprehensive surveys of income rather than consumption.

How sensitive are estimates of absolute welfare, poverty rates, and inequality to the difference between measuring consumption and income? We use micro data from the most recent household income and expenditure survey in Mexico (Encuesta Nacional de Ingresos y Gastos de los Hogares, 2012) to perform simple empirical comparisons between estimates based on income and estimates based on consumption expenditure.

At the national median, household net market income in Mexico in 2012 was about $\$ 8.04$ per capita per day, ${ }^{48}$ disposable income was slightly higher at $\$ 8.22$ per capita per day, and consumption expenditure significantly lower at $\$ 5.58$ per capita per day (calculated at the mean: $\$ 13.77, \$ 13.98$, and $\$ 9.17$, respectively). In the case of Mexico, using income as opposed to consumption as an indicator of the level of well-being is associated with an increase of about 44 percent at the median or 50 percent at the mean. ${ }^{49}$

Figure A.1 below plots household disposable income, total consumption expenditure, andfor reference-food consumption at the median of each decile of the household income distribution.

46 See Deaton and Grosh (2000) for an explanation of this argument, as well as other theoretical and practical considerations. Deaton and Muellbauer (1980) and Deaton and Zaidi (2002) provide a more comprehensive treatment.

47 In our dataset of 923 surveys from low and middle-income countries exported from the World Bank's PovcalNet, 357 use income as welfare measure. This number, however, overstates the coverage of income surveys over time and across regions: 80 percent of all income surveys were administered with relatively high frequency in Latin America and the Caribbean, and only four countries outside of Latin America conducted more than three cross-sections using income (Belarus, Poland, Latvia, and Malaysia). When restricting our sample to the latest survey in each country in circa 2010, Malaysia is the only country outside of Latin America that measures welfare using income. The only "outlier" in welfare measurement among developing countries is hence Latin America.

${ }^{48}$ Consistent with the rest of the paper, we convert prices to 2005 and convert Mexican peso into 2005 PPP dollar using the household consumption conversion factor from the International Comparison Program.

${ }^{49}$ This relationship is at odds with comparable estimates for Mexico provided by the World Bank's PovcalNet software, which may be related to the construction of our income and consumption variables. For 2010 PovcalNet reports mean consumption of $\$ 10.62$ a day and mean income of $\$ 9.46$ a day. 
Figure A.1: Household disposable income, total consumption, food consumption (Mexico, 2012)

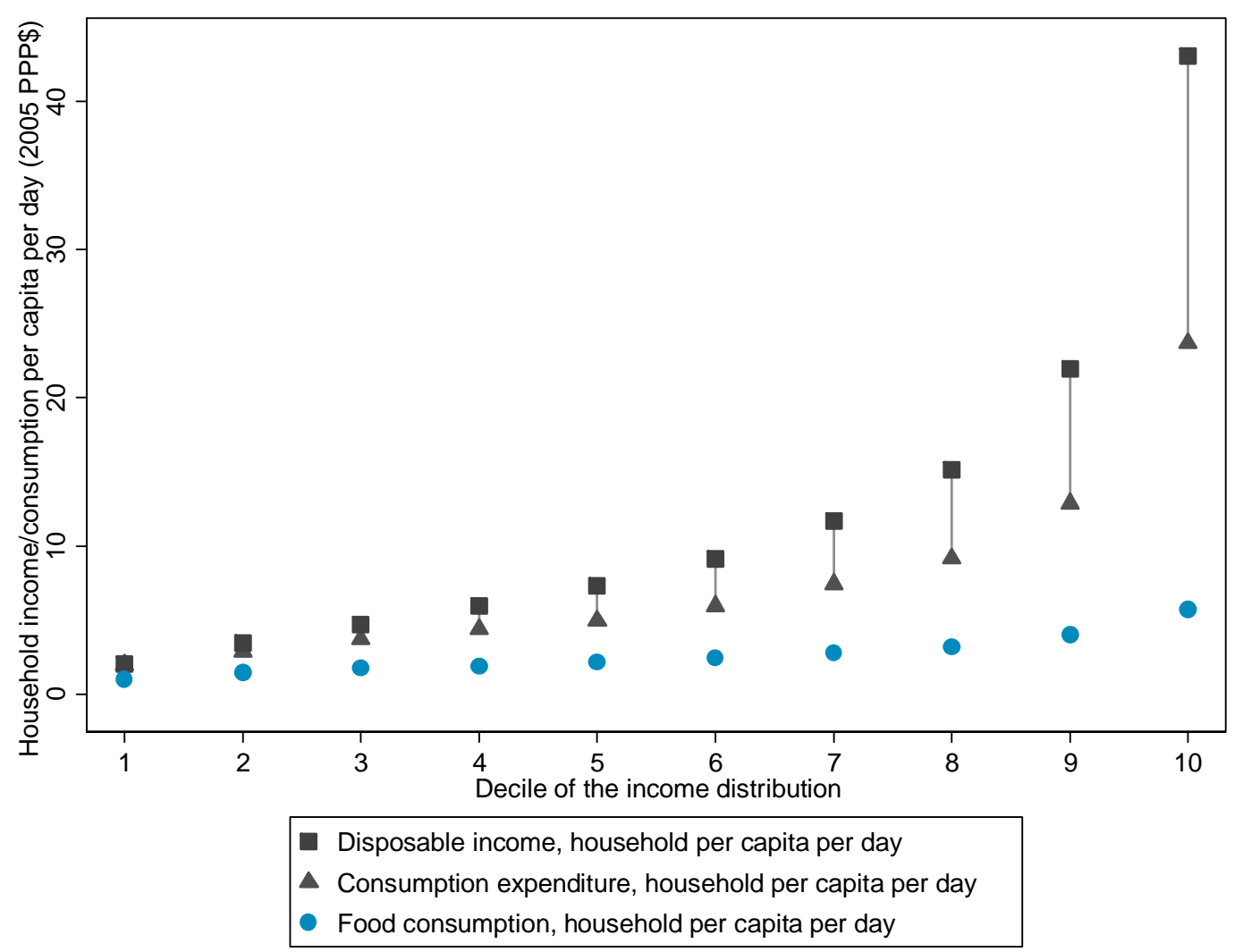

\footnotetext{
Note: Ratios are calculated at the decile median. Variable construction follows ENIGH's "new construction" method (INEGI, 2013a). Net market income is earned income, plus income from rents, plus private transfers, plus imputed rent for owner-occupied housing, less taxes. Disposable income is net market income plus government transfers.

Source: Authors' calculations, based on data from Mexico Encuesta Nacional de Ingresos y Gastos de los Hogares 2012 (ENIGH).
}

Figure A.2 below similarly plots the ratios of total household consumption to disposable income, total consumption to net market income, and food consumed inside the household to total consumption expenditure. As expected, the share of consumption in total (net market or disposable) income and the share of food consumption in total consumption decrease with increasing household income-the classic Engel's law. The median household in the richest decile of the income distribution spends a little more than 50 percent of its (net market and disposable) income, while the median household in the poorest decile spends about 130 percent of its net market income and slightly more than its disposable income. Food shares reflect this pattern: In the median household of the richest decile of the income distribution, food consumed inside the household accounts for 14 percent of total consumption; in the poorest decile, food accounts for half of all household consumption expenditures. 
Finally, we examine the potential differences in measured inequality using income instead of consumption: In 2012, Mexico's Gini coefficient of household disposable income was 0.4750 (or 0.52 for the per capita household disposable income distribution). As would be expected given our findings above and the illustration in Figure A.2, the Gini coefficient of the household consumption distribution is somewhat lower at 0.45 (or 0.5 when using the per capita household distribution). ${ }^{51}$ Similarly, the ratio of the mean to the median as a simple skewness measure is lower for the consumption distribution than for the income distribution.

Figure A.2: Household consumption expenditure as share of net market income and disposable income, food share (Mexico, 2012)

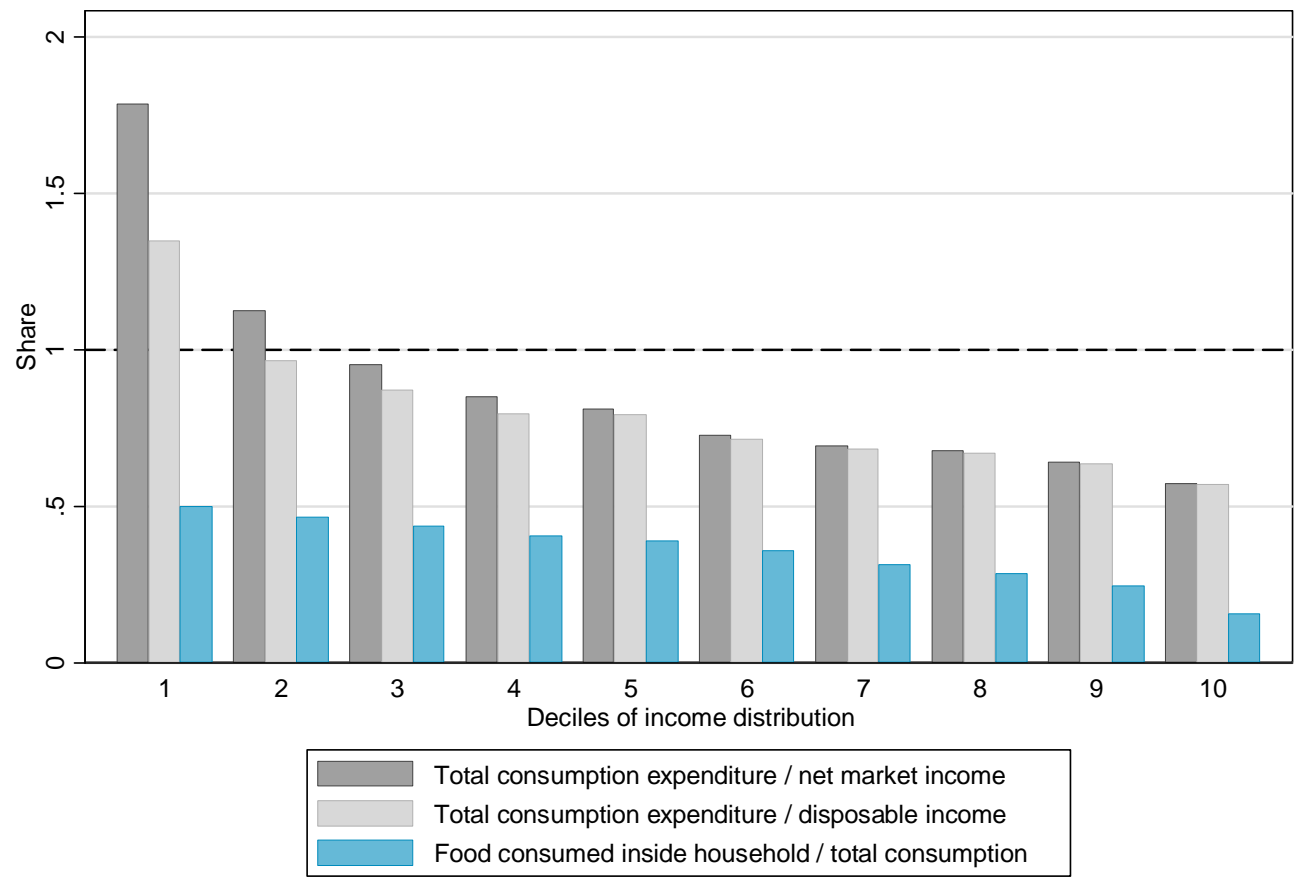

Note: $\quad$ Ratios are calculated at the decile median. See Figure A1 for explanation of variable construction.

Source: Authors' calculations, based on data from Mexico Encuesta Nacional de Ingresos y Gastos de los Hogares 2012 (ENIGH).

50 This is in line with the official figures provided in INEGI (2013b, p. 12).

51 These numbers are close to the estimates reported by the World Bank's PovcalNet tool, which for Mexico in 2010 reports a Gini of 0.48 using income and 0.47 using consumption as a welfare measure. 